\title{
GAYRIVIENKUL DÂVALARINDA
}

YETKİ

\author{
)
Dr. Ergun ÖNEN
Ankara Hukuk Fakültesi
Medenî Usûl ve İcra - İflâs Hukuku
Asistanı

\section{GENEL VE ÖZEL YETKI \\ II YABANCI HUKUKTA GAYRIMENKUL DÂVALARINDA YETKI MESELESİ}

A - Roma Hukukunda
B - Alman Hukukunda
C - İsviçre Hukukunda

1) Genel olarak

2) Özellikle Neuchâtel Kantonunda

III

TÜRK HUKUKUNDA GAYRIMENKUL DÂVALARINDA YETKI MESELESİ

A - Hukuk Usûlü Muhakemeleri Kanunurıdan önce

B - Hukuk Usûlü Muhakemeleri Kanunundan sonra

1) Gayrımenkul mahkemesinin kesin yetkisi

2) «Gayrımenkule ilişkin dâva» teriminin kapsamı

3) HUMK m. 13'e göre gayrimekule ilişkin dàvalar

a) Gayrımenkulün aynına ilişkin dâvalar

b) Gayrımenkul üzerinde bir hakka ilişkin olan dâvalar

aa) İtifak haklarında yetki

bb) Gayrımenkul mükellefiyetinde yetki

cc) Gayrımenkul rehninde yetki

c) Gayrımenkulün zilyedliğine ilişkin dâvalar

d) Gayrımenkuller üzerindeki hapis hakkına ilişkin dâvalar

4) Gayrımenkullerle alâkalı dâvalardan HUMK m. 13'ün kapsamına girmeyenler 
5) Gayrımenkullere ilişkin nizasız kaza ișlerinde yet. kili mahkeme

6) Dâvanın birden çok gayımenkule ait olması

7) Gayrımenkulün birden çok mahkemenin yargi çevresinde bulunması

a) Gayrımenkulün fiilen bulunduğu yer

b) Gayrımenkulün birden fazla yargı çevrosinde bulunması halinde yetkinin tâyini

c) Gayrımenkiulün hangi yargı çevresinde bulundıgunun kesin olarak bilinmemesi

8) Adlî teşkilâtta yapılan değişiklik sebebiyle gayrımenkulün yeni bir mahkemenin yetkisine tâbi olması

IV GAYRIMENKUL DÂVALARIYLA İLGILİ DİĞER MESE LELER

1) Gayrımenkullere ilişkin hükümlerin icrası

2) Karşılık dâvanın 13 üncü maddenin yetkisine giren bir meseleye ilişkin olması

3) 13 üncü maddeye ilşkin uyuşmazlıklar dolayısıyla alınacak ihtiyatî tedbirler için yetkili mahkeme

4) Gayrımenkul dâvalarında görev

5) Gayrımenkul dâvalarında tahkim

a) Gayrımenkul dâvalarında ihtiyarî tahkim

b) Gayrımenkul dâvalarında mecburî tahkim 
ACEMOĞLU, Kevork : Türk Hukukunda Tapu Kütüğ̈üne kayıtlı olmayan gayrumenkullerin hukukî durumu (Doktora Tezi), Istanbul 1965.

AHMET ZIYA : Usalü Muhakemei Hukukiye Kanunu Şerhi c. I. İstanbul 1322.

AKGÜN, M. Zerrin : Mer'a Hukuku, Adalet Dergisi 1953, S. 1 s. 3 vd.

AKIPdK, Jale : Türk Eşy Hukuku (Aynî Haklar) c. I, Zilyedlik ve Tapu Sicili, Ankara 1965.

ANSAY, Sabri Şakir : ¿xukuk Yargllama Usulleri, 7. Bası, Ankara 1960. ATASAYAN, Tacettin : Hukuk Muhakemeleri Usulü - İçtihatlar Külliyıyatı, - 1954.

BELGESAY, Mustafa Reşit : Hukuk Usulü Muhakemeleri Kanunu Şerhi c. I, İtanbul 1939.

BERKt, Osman Fazil : Devletler Hususi Hukuku, 2. Bası, İstanbul 1956. BLLGE, Necip : Hukuk Muhakemeleri Usulü Kanunu (HMUK), Ankara 1961.

BiLGE, Necip : Medenî Yargllama Hukuku (MYH), 2. Bası, Ankana 1967. BLOMEYER, Arwed : Zivilprozessrecht, Berlin 1963.

BöCKLI, Otto : Zivilprozessordnung für den Kanton Thurgau-mit Anmerkungen, Anhang und Sachregister -, Frauenfeld und Leipzig 1930.

CANSEL, Erol : Türk Hususî Hukukunda Hapis Hakkı, Ankara 1961. von der CRONE, Hugo : Der Gerichtsstand der gelegenen Sache, Winterthur 1955.

GATALKAYA, Cevdet - TARIKoĞULLARI, Abdurrahman : Yeni İçtihatli Hukuk Usulü Muhakemeleri Kanunu (t/stihatlı HUMK), Ankara 1965.

CATALKAYA, Cevdet-TARIKoGullar, Abdurrahman : Kat Mulkiyeti Kanunu Şerhi (KMKS్S), Anikara 1966.

DEMIRHAN, H. Orhan - TAZEBAY, Iksev : Hukuk Muhakemeleri Usulü Kanunu-Usulle ilgili Kanun ve Içtihatlar-c. I, Ankara 1965.

DíNGER, Selâmi - KAZANCI, Sadi : Haşiyeli Hukuk Usulü Muhakemeleri Kanunu ve Usul Hükümlerini intiva eden diğer mevzuat, Ankara 1954. ERSOY, Rufat : Notlu - Izahlı - Içtihatı Hukuk Usulü Muhakemeleri Kanunu, Ankara 1966.

GökTƯRK, Hüseyin Avni : Türk Medenî Hukuku c. IV -Aynî Haklar-, Ankara 1949.

GROSSEN, Jacques-Michel : Cours de procédure civile, Neuchâtel 1959 1960.

GULDENER, Max : Schweizerisches Zivilprozessrecht, 2. Aufl., Zürich 1958.

HOLLWEG, Bethmann : Der römische Zivilprozess, Bd. II, III, Bonn 1865. 1866 (değiştirillmemiş yeni baskusıl 1959). 
IMRE, Zahit : Gayrımenkuller üzerinde hapis hakkı dermeyan edilebili: mi?, İstanbul Barosu Dergisi c. XXVI S. 3.

KARAF AKİH, İsmail Hakkı : Hukuk Muhakemeleri Usulü Esasları, Ankar 1952.

KARAOK, Hasan : Hukuk Usulü: Muhakemeleri Kanunu -İçtihatlar,_, 2. Bas1, 1957.

KELLER, Gottfried : Die Zivilprozessordnung für den Kanton Aargau -mit Erlaeuterungen, - 3. Aufl., Aarau 1947.

KURU, Baki : Nizasız Kaza (NK), Ankara 1961.

KURU, Baki : Hukuk Muhakemeleri Usûlüi (HMU), Ankara 1964

KURU Baki : İcra ve İflâs Hukuku c. I - İcra Hukuku- (İH), Ankara 1965.

LENT, Friedrich - JAUERNIG, Othmar : Zivilprozessrecht, II. Aufl., München und Berlin 1963.

LEUCH, Georg : Die Zivilprozessordnung für, den Kanton Bern, 3. Aufl.. Bern 1956.

ÖMERBAs, Lütfi- QETiNTAș, Sacit : Temyiz Mahkemesi Hukuk Genel Kurulu Emsal Kararlar'ı ve İçtihadı Birleştinme Kararları c. I, III, Ankara 1953,1960 .

ÖZTEK, Esat - KAZANCI, Sadi : Nazarî ve Tatbikî Içtihatlı Hukuk Usulü Muhakemeleri Kanunu, Ankara 1957.

PostacioĞLU, İhan E. : Medenî Usûl Hukuku Dersleri, 3. Bası, İstanbul 1966.

REİSOĞLU, Safa : Türk Eşya Hukuku c. I «Giriş-Zilyedlik- Tapu Sicili», Ankara 1965.

ROSENBERG, Leo : Lehrbuch des deutschen Zivilprozessrechts, 9. Aufl., München und Berlin 1961.

SAYMEN, Ferit Hakkı - ELBÍR, Halit Kemal : Türk Eşya Hukuku Dersleri, Ístanbul 1963.

SCHÖNKE, Adolf : Lehrbuch des Zivilprozessrechts, 8. Aufl., Karlsruhe 1956.

SEVİĞ, Vedat Raşit : Ticarî Sahadaki Kanunlar İhtilafı, Istanbul 1958.

STEIN, Friedrich - JONAS, Martin : Kommentar zur Zivilprozessordnung Bd. I, 18. Aufl., Tübingen 1953.

VELIDEDEOĞLU, Hıfzı Veldet - ESMER, Galip : Gayrmenkul Tasarrufları ve Tapu Sicili Tatbikatı , 2. Bası, İstanbul 1956.

WIECZOREK, Bernhard : Zivilprozessordnung und Gerichtsverfassungsgesetz, Berlin 1960.

WIELAND, C. : Kanunu Medenide Ayni Haklar. (Çev. I. H. Karafakı), 2. Bas1, Ankara 1946

Türk Hukuk Lü̈gatı, Ankara 1944.

Usûlü Muhakematı Hukukiye ve Mevaddi mezyle ve Izahnamesi 1327 - 1329,

Kavanini Cedíde Kütüphanesi 1, İstanbul. 


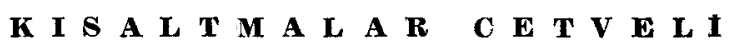

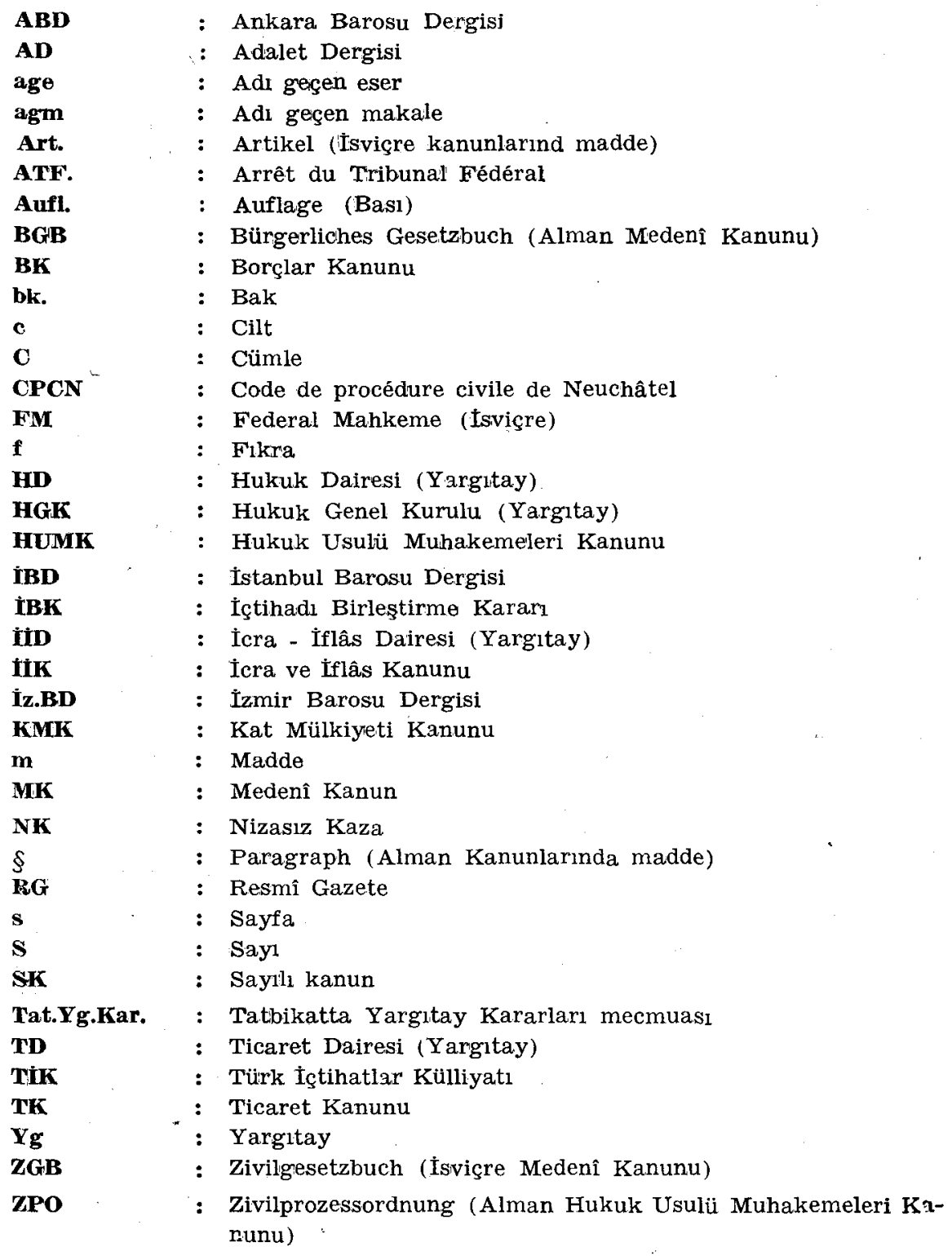




\section{GAYRIMENKUL DÂ VALARINDA YETKİ}

\section{I - GENEL VE ÖZEL YETK 1}

Yetki (1) kaideten bir yerin mahkemesinde dâva açmak zorunluluğunu değil, aksine o mahal mahkemesinde dâva açmak imkân:$\mathrm{n}$ ifade eder. Gerçekten kesin yetki halleri dışında kalan hususlarda dâvacı seçimlik bir hakkı haizdir. Şöyle ki, dâvacının dâvasırıı açmak imkânına sahip olduğu mahkeme birden çok ise, dâva bunlardan birisinde açılmakla bir seçim yapılmış ve artık o mahkemenin yetkisi kabul edilmiş olur. Fakat bu durum diğer yetkili mah. kemelerin yetkisini tamamen kaldırmış olmaz. Kesin yetki tabiatryla bu söylenenlere bir istisna teşkil eder (2).

Prensip, dâvaların dâvalının ikametgâhı mahkemesinde (3) açılması şeklindedir. Bu esas Hukuk Usulü Muhakemeleri Kanunumuzda (HUMK) «Her dâva ikame eàildiği tarihte müdeaaleyhin Kanunu Medenî mucibince ikametgâhı addolunan mahal mahkemesinde bakılır» sözleriyle kanunî ifadesini bulmuştur (m. 9/1). Genel yetkiyi tayin eden bu esasın yanı sura dâvanun istisnaî olarak başka bir yer mahkemesinde açllabileceğini öngören özel yetkj hallerini düzenleyen hükümler de HUMK. muzda yer almış bulunmaktadır (4). Bu istisnai yetki kaidelerinden bir kısmı seçimlik ka-

(1) Yetki burada dar anlamaa kullanılmıştır. Yani sadece coğrafî saha itibariyle bir mahkemenin işe bakma iktidarını belirtmek için kullanılmış olup, yer itibariyle yetkiyi (örtliche Zustaendigkeit, compétence territoriale) ifade eder. Geniş anlamda yetki kavramının kapsamına giren ve mahkemelerin şey (madde) yönünden bir dâvaya bakma yeteneğini ifade eden görev (sachliche Zustaendigkeit, compétence en raișon de la matière) kavramı buraya dahil değildir.

(2) Ansay, Hukuk Yargilama Usulleri, 7. Baski, Ankara 1960 s. 90; Schönke, Lehrbuch des Zivilprozessrechts, 8. Aufl., Karlruhe 1956, \$ 39 III; Rosenberg, Lehrbuch des deutschen Zivilprozessrechts, 9. Aufl., München und Berlin 1961, \& 33 IIr.

(3) Ikametgâh burada MK. m. 19 anlamında kullanılmıştır; bk. ayrıca MK m. 21, 49.

(4) HUMK m. 10 vd. Ayrıca özel kanurilarla belirtilmiş olan özel yetki halleri mevcut olup, bunlar Usûl Kanununca da mahfuz tutulmuslardır. (bk. m. 24). Meselâ Medenî Kanun, Ticaret Kanunu, Icra ve İflâs Kanunu, Tapulama Kanunu, İstimlâk Kanunu vs. 
rakterde olup, ana kaidenin yanı sıra ve onunla birlikte hüküm ifade ederler (5), diğer bir kısım özel yetki kaideleri ise inhisar̂ mahiyette olup ana prensibi tamamen bertaraf ederler. Bu sonuncu halde yetki kesin olup (6), tayin edilen bu yetki dışında bir yetkinin kabulü imkânsızdır (7). İşte gayrımenkul dâvalarında yetkiyi hükme bağlayan Usûl Kanunumuzun 13 üncü maddesi de böyle istisnaî ve inhisarî mahiyette bir kesin yetki halini düzenlemiştir.

\section{II - YABANCI HUKUKTA GAYRIMENKUL DÂVALARINDA YETKI MESELESI}

A - R o m a $\mathrm{H} \mathrm{uk} \mathrm{uk} \mathrm{u} \mathrm{n} \mathrm{a}$

Roma Hukukunda genel yetkinin (forum generalis) yanı sira çok eski zamanlardan beri akdin yapıldığ 1 yer mahkemesi (forum contractus), haksız fiilin işlendiği yer mahkemesi (forum delicti commissi), müddeabihin bulunduğu yer mahkemesi (forum rei sitae) vs. gibi özel yetki halleri de yerleşmiş bulunmaktaydı.

Roma gayrimenkulleri üzerinde ancak medenî hukuka has şekillerle mülkiyet hakkı ve irtifak hakları tesis edilebiliyordu. Fetihler sonucu elde olunan toprakların tamamı, bütün eyaletler arazisi jus gentium'a (8) tabî bulunmaktaydı. Buna mukabil taşınabilir malların hukukî durumları ise, bunların değişebilen karakterlerine göre değil, aksine iktisap eden şahsin hukukuna göre düzenlenirdi (9).

Forum rei sitae Roma Hukukunun daha önceki devirlerinde henüz tam bir aynilik karakterine bürünmemişti. Bu yetki sadece mallar hakkındaki icraî muameleler için kabul edilmiş olup, bu mallara ilişkin hukukî ihtilâfların halli bakımından uygulanmamaktaydı (10). Daha sonraları ise mülkiyete ilişkin istihkak iddiaları bakımından da forum rei sitae kabul edilmiş (11) ve böylece icraî iş

(5) Bunlar genellikle kesin yetki kaideleri dișında kalan hükümlerdir.

(6) Kesin yetki halleri için bk. HUMK m. 11/1, 13, 15, 17, C. 2; İ́K. m. 154; MK m. 136.

(7) Kesin yetki, yetki sözleşmesi (HUMK m. 22) yapma imkânını da kaldırır.

(8) Jus gentium için bk. Türk Hukuk Lügati, s. 564.

(9) Hollweg, Der römische Zizilprozess, c. II, Bonn 1865 (1959), § 751.

(10) Hollweg, age, c. II, \$ 72 I 2b, § 751.

(11) Valentinian, Theodos ve Arcadius tarafindan çlkarılan bir kanun ile (Hollweg, c. III, § 146). 
lemin artık sadece malın değerine değil, aksine bizzat mala müte veccih olması da sağlanmıştı. Nihayet Justinian tarafından bu yetki aynî mahiyette olan bütün dâvalara teşmil edilmişsir(12).

\section{B - A $1 \mathrm{~m}$ a n $\mathrm{H} \mathrm{uk} \mathrm{u} \mathrm{k} \mathrm{und} \mathrm{a}$}

Aynî karakterdeki dâvalara ilişkin yetki meselesi Alman Usûl Kanununun (ZPO) 24-26 ncı madelerinde düzenlenmiştir. Bu ay.nî yetki (13) $\$ 24$ te anılan hallerde kesin mahiyettedir. Halbuki müteakip maddelexde yâni $\$ \$ 25$ ve 26 nın tâyin ettiği durumlarda bu yetki kesin karakterde değildir. Zira 24 üncü maddenin aksine olarak bu iki maddede şahsî mahiyette olan muayyen bazı dâvaların da aynî yetkiye tabî olabileceği, yani ilgili oldukları gayrımenkul ile federal hukuka veya federe devletlerin hukuklarına göre gayrımenkuller gibi mütalaâ olunan hakların ilişkin olduğu malın bulunduğu yer mahkemesinde de açılabilecekleri kabul edilmiş$\operatorname{tir}(14)$.

Aynî yetki herşeyden evvel § 24 te zikrredilen ve aynî dâva denilen hallerde bahis konusu olur. Bunlar malın mülkiyetine, mal üzerindeki herhangi bir mükellefiyete veya malın böyle bir mükellefiyetle yükümlü olmadığına dair olurlar. Meselâ mülkiyet hakkının tesbitine, bu hakka tecavüzün ref'ine (BGB \& 1004) dair dâvalarla, komșuluk hakkından mütevellit dâvalar (BGB $\leqslant \$ 905$ vd.) vb. sibi. Eunun haricinde zilyedlik (BGB $\$ \S 861,862,1029,1090$ ) hudut tâyini (BGB $\$$ 919,920) ve taksim (BGB § 749) dávaları da 24 üncü madde dolayısıyla kesin aynî yetkiye tâbidirler (15).

$\$ 25$ deki hallerde aynî yetki müstakil olarak deŏil, aynî bir dâvayla bağımlı olarak öngörülmüştür. Başka bir ifádeyle, bu maddeye göre belli bazı șahsî dâvalar $\$ 24$ ün ayní dâvası ile bağlantı$l_{1}$ olarak bu aynî dâvanın ikame olunabileceği yer mahkemesinde

(12) Hollweg, age, c. III, \$ 146. Roma'da forum rei siate ve bunun Cermen ve eski İsviçre Hukukuna olan tesirleri hakkında daha geniș bilgi için bk. von der Corne, Der Gerichtsstand der gelegene: Sache, Winterthur 1955, $63-64$

(13) Aynî karakteri haiz dâvalar için Alman Hukukunda «Aynî yetki» terimi kullanilmaktadır.

(14) Bk. ZPO \$\$\$ 24-26; karş. Rosenberg, age. \$ 35 III 4.

(15) Karş. Schönke, age. \$ 40 III 1; Rosenberg, age. $\$ 35$ III 2 a; Blomeyer, Zivilprozessrecht, Berlin 1963, \$ 5 IV $3 \mathrm{~h}$; Lent - Jauernig, Zivilprozessrecht, 11. Aufl., München und Berlin 1963, s. 29. 
açılabilirler. Fakat bunun için bu dâvaların tevcih edildiği şahsın (dâvalının) aynı şahıs olmasıı şartı aranmaktadır (16). Misâl olarak aynı zamanda borçlu durumunda olan malike karşı açılmış bulu-nan ipotek ve alacak dâvaları gösterilebilir (17).

Aynî yetki dolayısıyle son olarak ZPO $\$$ ، daki halleri zikredebiliriz. Bu maddeye göre ne $\$ 24$ deki giiji tam bir aynî dâva, ne de $§ 25$ 'e göre aynî dâva ile birlikte açılmış bulunan şahsî bir dâva bahis konusudur. Bu sonuncu maddede söz konusu edilen dâvalar da muayyen bazı şahsî dâvalardır. Ancak bunlar \$ 25 de oldự̆unun aksine tamamen müstakil olarak açlabilirler. Eğer bu dâvalar bir gayrımenkulün maliki veya zilyedi aleyhine bunların maliklik ve zilyedlik vasıfları dolayısıyla açılmış bulunmaktaysa, bu takdirde o gayrımenkulün bulunduğu yer mahkemesi de yetkili olabilmektedir. Meselâ alıcıya karşı kira mukavelesinden doğan taleplei (BGB $\S 571$ ) bu kategoriye dahil bulunmaktadır. Bunun haricinde bir gayrımenkulün hasara uğramasından mütevellit dâvalar (BGB $\$ \S 823.867$ C. 2,904 C. $2,989,1005,1134$ ) ile yine bir gayrimenkulün istimlâk edilmesi dolayısıyla açılan tazminat dàvaları ilgili gayrımenkullerin bulundukları yer mahkemelerinde de görülebilirler (18).

Bütün bu söylenenlerden şu sonuca varılmaktadır: Alman Hukukunda aynî yetki kesin (inhisarî) ve kesin (inhisarî) olmayan şeklinde ikiye ayrılmaktadır. Kesin ve inhisarî aynî yetki sadece gayrımenkullere ve bunlara ilişkin aynî haklara taallûk etmektedir. Bunlara dair dâvalarda ancak müddeabihin mahkemesi yetkili olmaktadır. Kesin olmayan aynî yetkide ise esasen belli bazı şahsî dâvalar bahis konusu olmaktadırlar ve bunlarda dâvanın müddeabih mahkemesinde açılması kaydı mutlak değildir; ancak belli bir takım şartların varlığı halinde bu dâvaların müddeabih mahkemesinde de açllabilmeleri mümkündür.

(16) Karş. ZPO § 25.

(17) Misaller için bk. Schönke, age, § 40 III 3 a; Rosenberg, age. § 35 III 3 a; Blomeyer, age. $\S 5$ IV h; Lent-Jauernig, age. s. 29.

(18) Karş. Schönke, age. $\$ 40$ III 3 b; Rosenberg, age. $\$ 35$ III 3 b; Blomeyer, age. $\$ 5$ IV h; Lent-Jauernig, age. 29. 
$\mathrm{C}$ - İs vi çre H u k u k u d a

\section{1) Genel olarak}

Usûl Hukuku İsviçre'de federal değil kantonal karakterde olduğu için, bütün İsviçre'ye şâmil olan bir Hukuk Muhakemeleri Usulû Kanunu mevcut bulunmamakta, aksine medenî usûl hukukuna ilişkin meseleler her kantonun kendi usûl kanunu ile düzenlenmiş bulunmaktadır. Fakat şunu da belirtmek gerekir ki, birçok usûl hukuku meseleleri çeşitli kantonların usûl kanunlarında bazen aynen bazen de benzer şekillerde düzenlenmiş olup, önemli olabilecek ayrıcalıklar çok değildir. Gayrımenkul dâvalarında yetki bakımindan da durum bu merkezdedir (18a). Bu yetkiye tabî bulunan çeşitli mallar ve haklar hakkındaki dâvalar bakımından kantonlar arasında esas olarak üçlü bir guruplaşma tespit edebiliriz. Şöyle ki:

Gayrımenkul dâvalarında bahis konusu tașınmaz malın bulunduğu yer mahkemesinin yetkisi

a) Gayrımenkuller üzerindeki aynî haklara ilişkin dâvalar hakkında kesin yetki olarak;

b) Menkuller üzerindeki aynî haklara ilişkin dâvalar hakkıında genel yetkinin yanı sira seçimlik yetki olarak;

c) Ender olarak rehinle temin edilmiş alacaklar ve konusu bir gayrımenkul veya gayrımenkulle ilgili olan şahsî dâvalar için söz konusu olur (19).

Bunları ayrı ayrı inceleyelim :

a) Burada da meseleyi üç kısımda tetkik etmek gerekir :

aa) Kantonlardan birçoğu (20) gayrımenkulün bulunduğu yer mahkemesinin yetkisini, sadece gayrımenkuller üzerindeki aynî haklar bakımından kabul etmişlerdir;

(18a) İsviçre'de gayrımenkul dâvalarında yetki için bk. von der Crone, age.

(19) Guldener, Schweizerisches Zivilprozessrecht, 2. Aufl., Zürich 1958, s. $79-80$.

(20) Burada bu kantonların usûl kanunlarının ilgili maddeleri zikredilecektir: Bern 29, Zürih 6, Thurgau 14, Neuenburg 11, Schaffhausen 58, Tessin 19, Solothurn 22, Basel-Stadt 2, Basel-Land 22, Appenzell a. Rh. 33, Appenzell I-Rh. 29, Genf 57/4, Waadt 7, St. 
bb) Birkaç kanton (21) hem menkuller hem de gayrımenkuller üzerindeki aynî haklar bakımından açılan dâvalar hakkında gayrımenkulün bulunduğu yer mahkemesinin kesin yetkisini kabul etmişlerdir;

cc) Nihayet tek bir kanton (32) gayrımenkullerin üzerindeki aynî haklar bakımından ikame olunan dâvalar hakkında bile dâvacıyı dâvasını o gayrımenkulün bulunduğu yer mahkemesine veya genel yetkili mahkemeye götürmek hususunda serbest bırakmaktadir (23).

b)

aa) Bir takım kantonlar (24) menkuller üzerindeki bütün aynî haklar bakımından yukarda (b) bendi (25) altında zikredilen yetkiyi kabul etmişlerdir;

bb) Diğer bazı kantonlar (26) ise menkuller üzerindeki ayn⿳亠丷 haklardan yanlız rehin ve hapis hakkı için gayrımenkulün bulunduğu yer mahkemesinin yetkisini kabul etmişlerdir. Bahis konusı malın o gayrımenkule malikin veya zilyedin rızası olmaksızın getirilmiş olması halinde de bu gayrımenkulün bulunduğu yer mahkemesinde dâva açılabilecektir (27).

c) Yukarda (c) bendi altında zikredilen mevzuu «rehinle temin edilmiş alacaklar» olan dâvalar ekseriya aynî karakteri haiz

Gallen 88, Freiburg 65, Graubünden 23, Uri 40, Obwalden 14/II, Zug 5, Luzern 39, Schwyz 45. Schaffhausen, Bern ve Uri kantonlarının Usûl Kanunları ipotek alacağından mütevellit dâvaya ilişkin bir gayrımenkul rehin hakkının kabulüne dair uyuşmazlığın dâvalının ikametgâhı mahkemesinde görüleceğini hükme bağlamışlardır.

(21) Aargau 12/a, Nidwalden 13, Glarus $7 / \%$.

(22) Wallis 15.

(23) Guldener, age. s. 79.

(24) Appenzell a. Rh. 33, Appenzell I-Rh. 25, Luzern 39, Graubünden 23, St. Gallen 93, Bern 29, Basel-Land 22.

(25) Bk. dipnot 19 civarı.

(26) Wallis 17, Schwyz 54, Zürih 11, Schaffhausen 59, Thurgau 8, Zug 5, Basel - Stadt 2.

(27) Guldener, age. s. 79-80. 
dâválar olarak mütalâa olunmaktadırlar (28). Yine adı geçen bentte söz konusu edilen «gayrımenkulle ilgili bulunan şahsî dâvalar * dan kasıt, gayrımenkulün âdî kiraya ve hasılat kirasına verilmesinden doğan dâvalarla gayrımenkuller üzerinde bir is vapılmasm dan mütevellit dâvalardır (29). Bütün bu dâvalar da gayrımenkulün bulunduğu yer mahkemesinde açlacaktır (30).

\section{2) Özellikle Neuchatel Kantonunda}

Gayrımenkul dâvalarında yetki mehaz Neuchatel Usûl Kanununun (CPCN) 11 inci maddesinde düzenlenmiştir. Bu maddenin birinci fıkrasında «aynî olsun şahsî olsun gayrımenkule ilișkin hor dâva o gayrımenkulün bulunduğu yer mahkemesinde açılır» denilmektedir. Flkranın ifadesinden anlaşılacağı üzere mehaz kanun forum rei sitae'yi gerek aynî gerek şahsî dâvalar (Hukuk Usulû Muhakemeleri Kanunumuzun aksine) bakımından kabul etmiș bulunmaktadır (31). Aynı maddenin ikinci fıkrasına göre «Gayrımenkule ilişkin dâva sebebi ne olursa olsun gayrımenkulün aynına vey:i gayrımenkul üzerinde bir hakka veya geçici olsa bile o gayrimenkulü elde tutma hakına (32) yahut onun zilyedliğine dair olandır, denilmektedir.

Görüldüğü gibi mehaz kanunda 11 inci maddenin birinci fıkrasinda konulan genel prensipten sonra, ikinci fıkrasında gayrımenkule ilişkin dâvaların neler olabileceği gösterilmiştir. Aynî dâvalàrın forum rei sitae'ye tabî olmaları bakımından tereddüt' mevcut değildir. Fakat acaba gayrımenkule ilişkin şahsî dâvalar yönünden durum ne merkezdedir? Zira bu gibi dâvalar çoğu zaman mixt kàrakterde olup gerek malın bulunduğu yer mahkemesinde, gerek

(28) Guldener, age. s. $80 / 23$.

(29) Guldener, age. s. 80; bk. ayrıca dipnot 24.

(30) Fakat bunun için dâvalının halihazır ikametgâhının da o kanton dahilinde bulunması gerekir. Zira aksi halin kabulü Federal Anayasanın 59 uncu maddesi hükmüne aykırı olur (Guldener, age. s. $80 / 24$.

(31) HUMK. muzun mehaz kanunun 11 inci maddesine tekabül eden 13 üncü maddesine birinci flkradaki «aynî olsun, şahsî olsun» sözleri alınmamıstır. Bunun sebebi belli değildir. Ne HUMK. nun gerekçesinde, ne komisyon zaptında, ne de kanunun meclisteki müzakerelerine ait tutanak bölümlerinde bu hususta bir açıklamaya tesadüf edilememiştir.

(32) Elde tutma hakkı mehaz kanunda «droit à la détention» olarak ifade edilmiştir (bk. dip not $116-118$ civarı). 
dâvalının ikametgâhı mahkemesinde açılabilmektedirler (33). Fakat bunun aksine bir tanzim tarzının da kabil olabileceğini forum rei sitae'nin münhasır yetkisini hem gayrımenkullere ilişkin aynı hem de şahsî dâvalar için kabul eden mezkûr 11 inci madde hükmü göstermektedir.

Öte yandan Federal Mahkeme (FM) gayrımenkule ilişkin şahsî dâva terimini geniş olarak yorumlaya taraftar bulunmaktadır. $\mathrm{Bu}$ cümleden olarak bir taraftan Neuchatel Kantonu Temyiz Mahkemesince, «bir gavrımenkulün satış bedelinin ödenmesi hakkındäki dâvanın CPCN m. 11/II deki anlamda şahsì bir gayrımenkul dâvası olduğu» kabul edilmekte (CCC VI 59), buna mukabil gayrımenkule ilişkin şahsî bir dâvanın gayrımenkulün satışının feshine ilişkin bir dâva mahiyetini alacak şekilde nitelendirilmesi FM'ce reddedilmektedir (ATF 69 I 5) (34).

Mehaz kanuna göre eğer gayrımenkul veya gayrımenkuller birden çok yerde bulunmaktaysa seçim hakkı dâvacıya aittir (m. 11/III). Son olarak irtifak hakkına dair iddialar bakımından, üzerinde irtifak hakkı tesis edilmiş olan (hâdim) gayrımenkulün bılunduğu yer mahkemesinin yetkili olacağı (m. 11/IV) kabul edilmiş bulunmaktadır.

\section{III - TÜRK HUKUKUNDA GAYRIMENKUL DÂVALARINDA YETKİ MESELESI}

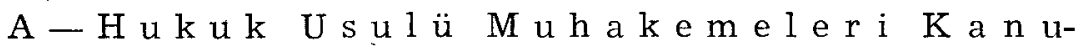 $\mathrm{n} u \mathrm{nd}$ a $\mathrm{n} \ddot{\mathrm{o}} \mathrm{nce}$

Türkiye'nin ilk usûl kanunu olan 1295 (1878) tarihli Usûlü Muhakematı Hukukiye Kanununda gayrımenkul dâvalarında yetki konusu müstakil olarak düzenlenmemişti. Fakat kanunî bir hükmün yokluğuna rağmen bu mesele doktrin ve içtihatca incelenmiş ve nihayet 1327 (1911) tarihli Usulû Muhakematı Hukukiye Kanununa ek kanunun 1 inci maddesiyle gayrımenkul dâvalarında yetki kanunen düzenlenmiştir.

1327 tarihli kanunun yürürlüğe girmesinden once doktrinde nefsi akara ilişkin dâvaların görüleceği yer konusunda iki ayrı fi-

(33) Karş. BGB $\S 26$; Bern Huk. Us. Ka. $\$ 29$ I C. 2.

(34) Grossen, Course de procédure civile, Neuchatel 1959-1960, s. 74. 
kir bulunmaktaydı. Bir fikre göre, bu gibi dâvalarm da diğer dâvalar gibi dâvalının mensup bulunduğu yer mahkemesinde görülmeleri gerekmekteydi. Diğer bazı müellifler ise bu dâvaların uyuş. mazlık konusu olan akarın bulunduğu yer mahkemesinde açılması icabedeceği görüşünü savunmaktaydılar ki, ikinci görüş Mahkemei Temyizin (fii) 24 Rebiülevvel (sene) 98 tarihli bir ilâmı (35) ile de teyit edilmiş bulunmaktaydı (36).

Kanunda bir açıklık bulunmayışından ötürü o gün için bu gi. bi dâvaların normal olarak dâvalının ikametgâhı mahkemesinin yetkisine (genel yetki) tabî olacağı tezini savunanlara karşı tamamen yeni olan bu ikinci benimseyenler, yani akara ilişkin dâvalar için müddeabihin bulunduğu yer mahkemesinin yetkisini kabul edenler görüşlerininin dayanağı olarak aşağıdaki gerekçe. yi (37) ileri sürmekteydiler :

Evvelâ akar dâvalarının akarın vâki olduğu mahal mahkemesinde görülmesi Mecellenin 1807 nci maddesi hükmü icabındandır. Fakat bir akardan dolayı dâvacı o akarm bulunduğu yer mahkc. mesine değil de dâvalının ikametgâhı mahkemesine başvurmuş ve dâvacı da bu hususta bir itirazda bulunmamıș olursa o zaman dâvanin bu mahkemede görülmesi caiz olabilecektir. Bununla beraber bu cevazın gerekeni bozamıyacağı esasma istinaden akara ilşkiu dâvaların - dâvalının ikametgâhı nazarı itibara alınmayarak - doğrudan doğruya müddeabihin bulunduğu yer mahkemesinde açılması gerekecektir. Saniyen dâva dolayısıyla müddeabihin keşfine, zilyedliğin şahsî beyyine ile ispatına veya şahitlerin mahallinde irae ve tahdidine lüzum görüldüğü takdirde, dâvanın müddeabihin bulunduğu yer mahkemesinde değil de dâvalının ikametgâhı mahkemesinde açılmış olması pek çok güçlüğe sebep olacaktır. Nihayet her dâvanın dâvalının ikametgâhı mahkemesinde ‘çılması zarureti kolaylık temin etmek amacıyla kabul edilmiş bir esastır. Hal böyle iken akara ilişkin dâvaların o akarın bulunduğu kaza haricinde yani müddealeyhin ikametgâhı mahkemesinde ikamesi zorunluluğunun kabulü gerek dâvacı gerek dâvalının iddia ve müdafaalarının isbatı hususunda pek çok güçlüklere yol açacaktır. İşte bütün bu

(35) Bu ilâmın sureti için bk. Ahmet Ziya, Usulü Muhakemei Hukukiye Kanunu Şerhi, c. I, Ístanbul 1322, s. $85-86$.

(36) Bk. Ahmed Ziya, age. s. 85.

(37) Bk. Ahmed Ziya, age. s. $86-87$. 
sebeplerden dolayı bu fikri savunanlar akar dâvalarının müddeabihin bulunduğu yer mahkemesinde açılmasını ve görulmesinin gerekli olduğunu kabul etmekteydiler.

Doktrinde mevcut olan bu görüş ayrılığı nihayet ikinci fikrin kabul edilerek bu yönde kanunî bir tanzim tarzına gidilmesiyle sonuçlanmıştır. Yukarda bahsedilen 1327 tarihli, 1295 tarihli Usûlü Muhakematı Hukukiye Kanununa ek Kanunun 1 inci maddesi içinde diğerleri meyanında şu hüküm de yer almıştır: «... Eınvali gayrımenkuleye mütealik mülkiyet ve tasarruf dâvaları bulunciukları mahal mahkemesinde fasl ü rüyet olunur. Sebep ve akitten mün. bais müteadit emvali gayrımenkuleye taallûk eden. dâva emvaii mezkûrenin bulunduğu mahallerden herhangi birinin mahkemesinde ikame olunabilir». (38). Bu suretle gayrımenkule ilişkin dâvalar bakımından o gayrımenkulün bulunduğu yer mahkemesinin kesin yetkisi kaidesi Türk Hukukuna ilk olarak bu hüküm ile gir. miş ve 1927 yılında bugünkü Hukuk Usûlü Mahkemeleri Kanununumuzun yürürlüğe girmesine kadar uygulanmıștır.

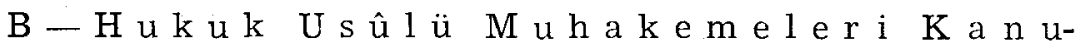
$\mathrm{n} u \mathrm{nd}$ a $\mathrm{n}$ s o n $\mathrm{r}$ :

\section{1) Gayrımenkul mahkemesinin kesin yetkisi}

HUMK muza göre «Gayrımenkule müteallik dâvalar gayrımenkulün bulunduğu mahal mahkemesinde ikame olunur» (m. 13/I) (39). Hernekadar bu yetkinin emredici ve dolayısıla kesin nitelikte olduğuna dair kanunda açıklık yoksa da, bu durum doktrin ve içtihat tarafindan ittifakla kabul edilmekte ve genel olarak gayrımenkul dâvalarındaki yetkinin inhisarî özelliğinden ve kamu dü-

(38) Usûlu Muhakematı Hukukîye ve Mevaddi mezyle ve izahnamesi, 1327 - 1329, Kavanini Cedîde Kütüphanesi 1, Istanbul, s. 52.

(39) $\mathrm{Bu}$ esas gayrımenkulün yabancı memlekette bulunması halinde bile uygulanmaktadir (bk. TD. 22.6.1954, 3695/4078 «Karaok, Hukuk Usûlü Muhakemeleri Kanunu - İçtihatlar -, 2. Bası, 1957, m. 13 No. 13»; 5. HD. 14.1.1950, 3091/188 «Demirhan — Tazebay, Hukuk Muhakemeleri Usûlü Kanunu -Usulle ilgili kanun ve içtihatlar-c. 1, Ankara 1965, m. 13 No. 1352»). Keza Türkiye'de bulunan gayrımenkule ilişkin bir dâvaya bakmak, dâvanın gayrımenkulün bulunduğu yerde görülmesi kaidesi gereğince, ilgili Türk mahkemesinin mutlak yetkisine tâbîdir (karş. Bilge, Medenî Yarglama Hukuku, 2. Bası, Ankara 1967, s. 3561 a). 
zeni ile olan ilgisinden bahsedilmektedir (40). Bu yetkinin kamu düzeninden bulunduğunun kabul edilmesinin pratik sonucu ise. bunun münhasıran bir ilk itiraz sebebi (HUMK m. 187/2) teşkil et. memesi ve yetki sözleşmesi (HUMK m. 22) ile bertaraf edilememesi, aksine re'sen ve ayrıca dâvanın her halinde (HUMK m. $23 \mathrm{C}$. 2) (40) hattâ ilk olarak Yargitayda bile nazarı itibara alınabilmesi (41) olacaktır.

Burada bu yetkinin kamu düzeninden olduğunun kabul edilmesi zorunluluğunu doğuran sebeplerin neler olduğu gibi bir soru muhakkak hatıra gelecektir. Genellikle kabul edildiğine göre, bunun en belli başlı sebebi, gayrımenkullere ilişkin dâvaların o gayrımenkulün bulunduğu yer mahkemesinde başka bir yer mahke. mesine nispeten çok daha serî, kolay, zahmetsiz, emin ve az mas. rafla görülmesinde aranmak gerekir. Gerçekten bu giibi dâvalar ekseriya mahallinde şahit dinlenmesi, keşif yapılması gibi bir takım usûl muamelelerini de icabettireceklerdir (42). Bütün bu işlerir. yapılmasında ise, başka bir yer mahkemesinin yetkisinin kabul edilmiş olması dolayısıyla istinabe yoluna başvurulması fuzuli ba. zl masraflardan başka, emek ve zaman bakımından da israfa sebebiyet vereceğinden, gayrımenkul dâvalarında o garyımenkulün bu* lunduğu yer mahkemesinin yetkisinin kabul edilmesinin pratik ve faydalı sonucu daha iyi anlaşılmış olacaktır. Isste bu düşünceler gayrımenkul dâvalarında yetki bakımından münhasıran gayrımenkulün bulunduğu yer mahkemesinin söz konusu olması gerektiğini haklı

(40) Ansay, age. s. 93; Postacıŏ̆lu, Medenî Usûl Hukuku Dersleri, 3. Bası. İstanbul 1966, s. 115, 293 - 294; Bilge, MYH s. 176; Kuru, Hukuk Muhakemeleri Usulü, Ankara 1964, s. 114, 128; 5. HD. 29.12.1953, 5733/6596 (Öztek-Kazancı, Nazarî ve Tatbikî İçtihatî̀ Hukuk Usulü Muhakemeleri Kanunu, Ankara 1957, m. 13 No. 231); 5. HD. 14.1.1950, 3091/188 (Dinçer-Kazanc1, Hâşiyeli Hukuk Usulü Muhakemeleri Kanunu ve Usul Hükümlerini ihtiva eden diğer mevzuat, Ankara 1954, m. 13 No. 9); 5. HD. 20.11.1950, 3721/1488 (Karaok, age. m. 13 No. 5); 1. HD. 2.4.1933 (Demirhan-Tazebay, age. c. I No. 1344); 1. HD. 21.9.1942, 2405/2109 (Karaok, age. m. 13 No. 2) 3. HD. 1.10.1981 (Demirhan-Tazebay, c. I m. 13 No. 1343); HGK. 7.6.1933, 3-59/91 (Karaok, age. m. 13 No. 1).

(41) Karş. Pastaciolğu, age. s. 115; Bilge, VYH s. 368; Kuru, HMU s. $114-115$; 4. HD. 10.2.1953, 801/613 (Atasayan, Hukuk Muhakemeleri Usulü - İçtihatlar Külliyatı-1954, m. 13, s. 113).

(42) Postacıoğlu, age. s. 115; Bilge, MYH s. 175; karş. dip not 37 civa$\mathrm{r}$ ve sonrası. 
gösterecek niteliktedirler. Hal bu merkezde iken, «tarafların iddialarını diğer bir yer mahkemesinde gördürmek hususunda kolaylıf: bulunması halinde bu yer mahkemesinin salâhiyetinin de kabul edilebileceğì şeklindeki fikirde (43) isabet göremiyoruz.

\section{2) «Gayrımenkule ilişkin dâva» teriminin kapsamı}

HUMK muzun 13. maddesinin birinci fikrasinda «Gayrımenkule müteallik dâvalar, gayrımenkulün bulunduğu mahal mahkemesinde ikame olunur» denildikten sonra ikinci flkranın birinci cümlesinde «Gayrımenkule müteallik dâva, sebebi ne olursa olsun gayrımenkulün aynına veya gayrımenkul üzerinde bir hakka veya muvakkat olsa bile onun zilyedliğine veyahut hakkı hapsine mütedair olanlardır» diye devam olunmaktadır. Bu hükmün sevkindeki gayenin ne olduğunu bir önceki paragrafta incelemiştik. Bu itibarla maddenin şu ifade şeklinden (44), kanun koyucunun hükme kabulündeki gayeden daha geniş bir anlam tanımış ve dolayısıyla asıl gayesini aşmış olduğu sonucuna varılabilir (45). Öte yandan kanunumuz birinci fıkradaki ifade şekliyle aynî olsun şahsî olsun gayrımenkule ilişkin bütün dâvaların ilgili gayrımenkulün bulunduğu yer mahkemesinde görüleceği ve netice itibariyle maddenin kapsamına gireceği gibi bir anlayışa sebebiyet vermektedir (46). Fakat ikinci fikranın tetkik edilmesiyle hemen anlaşlır ki, kanun koyucunun birinci fikradaki «gayrımenkule müteallik dâvalar» sözüyle kastettiği iddialar sadece şu ikinci fıkrada gösteriler nev'iden olanlar, yani gayrımenkulün aynına ilişkin bulunanlardır. Bir dâvanın gayrımenkulün aynına ilişkin olup olmadığını tam olarak ayırdetmek için ise şöyle bir kıstas kabul edilebilir: Eğer gayrımenkul, dâvada uyuşmazlığın doğrudan doğruya konusunu teşkil etmekteyse yani ihtilaf direkt olarak o gayrımenkule ilişkin olup, gayrımenku! dâvanın müddeabihi ise (47) uyuşmazlığın çözümünde yetkili mahkeme 13 üncü maddeye göre tayin edilecektir. Fakat eğer ihtila vasıtasız olarak o gayrımenkule ilişkin bulunmaz, aksine meselâ o

(43) Belgesay, Hukuk Usulü Muhakemeleri Kanunu Şerhi c. I, Istanbul 1939, m. 13 No. 5, s. $50-51$.

(44) Bu tanzim tarz1 genel olarak mehaz kanundakine de uygundur.

(45) Bk. Postacıŏlu, age. s. 115; Bilge, MYH s. 175 - 176.

(46) Karş. dip not 31 ve civarı.

(47) Karş. Böcekli, Zivilprozessordnung für den Kanton Thurgau, Fraıenfeld und Leipzig 1930, §14 No.4 Seymen-Elbir, Türk Eşya Hukuku Dersleri, Istanbul 1963, s. 513. 
gayrımenkul dolayısıyla doğmuş olan bir alacağa ilişkin bulunur ve gayrımenkulün bu dâvadaki rolü sadece endirekt olursa, bu takdirde uyuşmazlığın dolaysız müddeabihini şahsî bir hak olan bu alacak teşkil edeceğinden açlacak dâva 13 üncü madde anlamında bir gayrımenkul dâvası addedilemiyecek ve dolayısıyla yetki me. selesi maddenin kapsamma girmeyecektir (47a).

\section{3) HUMK m. 13'e göre gayrımenkule ilişkin dâvalar}

a) Ga yrimenkulü n a y n 1 n a i l is k i n d â v a 1 a r

aa) Gayrımenkule ilişkin dâvalar herşeyden evvel gayrımenkulün aynına taallûk edenlerdir. «Gayrımenkulün aynı» tabiriy’e kastedilen şey esas itibariyle o gayrımenkulün mülkiyetidir (48). Nelerin gayrımenkul olduğu MK. m. 632 de gösterilmiştir. Bu maddeye göre gayrımenkul mülkiyetinin konusu yerinde sabit olan şeylerdir. Bunlar da 1) Arazî (Liegenschaften, les bien fonds) (49). 2) Tapu sicilinde müstakil ve daimî olmak üzere ayrıca kaydedilen haklar (50) ve 3) Madenlerdir (51). Görülüyor ki bu maddede gayrimenkul mülkiyetinin konusunu müteharrik olmayan şeylerin teskil edebileceği açıkça belirtilmiştir. Bu durum karşısında gayrımenkul mülkiyeti (özellikle arazî) kavramının kapsamına normal olarak o gayrımenkulün mütemmim cüzlerinin de girmesi gerekir (52). Esasen bir arza malik olmanın onun altına ve üstüne malik olmak şeklinde anlaşılması gerektiği ve bu mülkiyetin normai olarak o arazîdeki yapılan ve dikilen şeyleri ve kaynakları kapsa. yacağına dair olan MK m. 644 hükmü de bunu doğrulayıcı mahiyettedir (53). Buna karşlık gayrımenkulün teferruatı o gayrımenkul ile birleşik olmakla beraber kendi başına bir varlık (sabit ol-

(47a) Kars, von der Crone, age. s. 27.

(48) Karş. MK m. 632 vd.; von der Crone, age. s. 32, 36.

(49) Karș. Tapu Sicil Nizamnamesi m. 3.

(50) MK m. 652, 751, 752.

(51) Bk. Maden Kanunu (3.3.1954, No. 6309 «G 11.3.1954, S. 8655»).

(52) Bk. MK m. 619; karş. von der Crone, age. s. 34.

(53) Kendi levazımı ile başkasının arsası veya başkasının levazımı ile kendi arsası üzerine yapilan inşaat ( $\mathrm{MK} \mathrm{m}$. 648), başkasının arsasina tecavüz eden inşaat ( $M K$ m. 651), MK m. 648'e kiyasen dikilen seyler (MK m. 655) kanunda öngörülen mütemmim cüz halleridir. Şu halde bu maddelere ilişkin uyuşmazlıklarda yetki HUMK m. 13'e göre düzenlenecektir. 
mayan bir menkul) teşkil ettiği içindir ki, m. 13 ün kapsamına girmeyecektir (53a).

Arazîden başka tapu sicilinde müstakil ve daimî olmak üzere ayrıca kaydedilen haklar da gayrımenkul mülkiyetinin konusunu teşkil ederler (MK. m. 632,'2) ve dolayısıyla yetki yönünden HUMK m. 13 ün kapsamina girerler. Bu haklar bir gayrımenkule veya şahsa bağlı olan haklar olmayıp tamamen müstakil mahiyette aynî haklardır (54); bunlar da başlıca üst hakkı (MK. m. 652), inşaat hakki (MK. m. 751) ve kaynak üzerindeki haktan (MK m. 752) ibarettir.

Son olarak madenler de MK. ve Mäden Kanununa göre müstakil karakterde gayrımenkul mal olarak kabul edilmişlerdir (55). Bunun tabii sonucu ise madenlere ilişkin dâvaların da 13 üncü maddenin kesin yetkisine girmesi olacaktır.

Bu esaslar çerçevesinde, fiilî, coğrafî durumu ve mahiyeti itibariyle «gayrımenkul kavramı kapsamına girmeyen şeylerin (ki bunların hemen hepsini menkuller teşkil edeceklerdir) 13 ünci madde yönünden mütalâa edilmeleri doğru olmayacaktır. $\mathrm{Bu}$ bakımdan buradaki «gayrımenkul» teriminin, $\mathrm{MK}$ m. 632 anlamında yerinde sabit olmayan fakat hukuken gayrimenkul addedilen mailara (İIK m. 23), özellikle gemi siciline kayitlı gemilere (TK $\mathrm{m}$. 840, 844) teșmil edilememesi gerekir (56).

bb) Kat Mülkiyeti Kanununun (57) 1 inci maddesine göre «Tamamlanmış bir yapının müstakil bölümleri üzerinde bağımsız mülkiyet hakları kurulabilir». Bu hüküm ile kat mülkiyetinin $\mathrm{MK}$ umuzda öngörülmemiş olan özel bir gayrımenkul mülkiyeti nev“i olduğu ifade edilmek istenmiştir. Bununla beraber bu konuda hüküm bulunmayan hallerde, kat mülkiyeti hakkında MK ile diğer

(53a) Aksi fikirde: Von der Crone, age, s. 34.

(54) Göktürk, Türk Medenî Hukuku c. IV -Aynî Haklar-, Ankara 1949, s. 813.

(55) Akipek, Türk Eşya Hukuku (Aynî Haklar) c. I -Zilyedlik Tápu Sicili-, Ankara 1965, s. $71-72$.

(56) Karş. Wieczorek, Zivilprozessordnung und Gerichtsverfassungsgesetz, Berlin 1960, § 24 B I c. Bununla beraber bağlama limanının (TK m. 819) yetkisi (TK $\mathrm{m} .841 / \mathrm{I}$ ) bakımından 13 üncü maddedeki yetkiye benzer karakterde bir durum söz konusu edilebilir (karș. von der Crone, age. s. 49).

(57) 634 SK. 23.6.1965 (RG 2.7.1965, S. 12038). 
ilgili kanunların hükümleri tatbik edilecektir (KMK m. 9). Şu izahattan kat mülkiyetinin konusunu teşkil eden şeylerin gayrımenkul veyd gayrımenkule ilişkin aynî bir hak olarak mütalâa edilme.sinin tabii olduğu anlaşllır. Bunun normal sonucu da kat mülkiyєtinden doğan aynî karekterdeki dâvaların HUMK. m. 13 ün kapsamina girmesi olacaktır.

Kat Mülkiyeti Kanunu çıkacak uyuşmazlıkların çözümlenmes: ve bu kanunun gerektirdiği çekişmesiz yargı işlerinin düzenlenmesi bakımından genel bir yetki kaidesi koymamıştır. Sadece kat maliklerinden birinin borç ve yükümlerini yerine getirmemesi halinde uyuşmazlığın ana gayrımenkulün bulunduğu yer getirmemesi halinde uyușmazlığın ana gayrımenkulün bulunduğu yer mahkemesince çözümleneceğini bildiren $\mathrm{m}$. 33/I ve maliklerin yönetici atanmasında anlaşamamaları halinde bunun ana gayrımenkulün bulunduğu yer mahkemesince yerine getirileceğini öngören $\mathrm{m}$. 34! VI hükmü bu konuda sarihtir. M. 25/II, 26/III, 28/III, 47/II, 52/III ve 54/II, III deki diğer hallerde ise yanliz mahkeme veya hakim. den bahsedilmiş olup, bunun hangi yer mahkemesi (hakimi) olacağı tayin edilmemiştir. Bununla beraber bu maddelerde bahis konusu edilen uyuşmazlıkların mahiyetleri icabı yetkili mahkemenin ana gayrımenkulün bulunduğu yer mahkemesi olacağı sonucuna varilir.

«Gayrımenkulün aynına ilişkin dâva» teriminin kapsamına mülkiyet dâvalarından başka istihkak dâvaları (MK m. 618) (58) da girer. Ayrıca müşterek mülkiyette taksim dâvası (MK. m. 627) (58a), izalei şuyu dâvası (59), sınır tayinine yardım dâvası (MK m. 646) (60) ve komşuluk hakkından doğan dâvalar (MK mı. 661 vd., 683) (61) da yetki yönünden ayne ilişkin dâvalar olmak dolayısıyle HUMK m. 13 e tâbî olurlar (62).

(58) ZGB Art. 641; karş. BGB § 985; karş. von der Crone, age. s. $32-33$.

(58a) Karş. von der Crone, age. s. 34.

(59) Bk. 2. HD. 12.9.1950, 1340/3917 (Atasayan, age. s. 114); ZGB Art. 650 ; karş. BGB $\$ 749$.

(60) ZGB Art. 669; karş. BGB $§ \S 919,920$.

(61) ZGB Art $684 \mathrm{vd}$. ve Art. 710; karş. BGB $\$ \$ 906 \mathrm{vd.}$

(62) Bk. Karafakih, Hukuk Muhakemeleri Usulü Esasları, Ankara 1952. s. 65; Leuch, Die Zivilprozessordnung für den Kanton Bern, 3. Aufl., Bern 1956, Art. 29 No. 1; Stein-Jonas, Kommentar zur Zivilprozessordnung I, 18. Aulf., Tübingen 1953, § 24 III 1; Wieczorek, age. $\$ 24$ B II b 1 . 
Bu hükümler dışında diğer bazı özel kanunlarda da gayrımenkul dâvalarına ilişkin yetki kaideleri yer almış bulunmaktadır. Özellikle Tapulama Kanununa (63) göre, tapulama işleriyle ilgili olmak üzere gayrımenkul mülkiyetine ve mülkiyetin gayrı aynî haklara, tapuya tescil veya şerh edilecek veyahut beyanlar hanesinde gösterilecek sair haklara, sınır ve ölçü uyuşmazlıklarına, tapulamaya ve tapu sicilini ilgilendiren sair benzeri dâvalara bakmakla gö. revli (m. 47/I) olan Tapulama Mahkemesının yer bakımından gö. revi, bulunduğu bölgedeki birliklerin (64) genel sinır krokisinde (65) belirtilen sinırlarla belli edilir (m. 49/I) (66).

Öte yandan İstimlâk Kanununun (67) 14 üncü maddesinin birinci fıkrasına göre «..... takdir edilen istimlâk bedeliyle maddî hatalara karşı gayrımenkulün bulunduğu mahal ..... mahkemesinde dâva açllacaktır» (68). Bu husus İstimlâk Kanunu yürürlüğe girmeden önce Yargıtay İçtihatları ile de mukarrer bulunmaktaydi (69).

(63) 766 SK. 28.6.1966 (RG 12.7.1966, S. 12346).

(64) Tapulama işleri için her ilin merkez ilçesi ile diğer ilçeleri birer «bölge», her bucak merkezi ile her köy birer «birlik» sayılır (Tap. Ka. m. 3/I).

(65) Tap. Ka. m. 18, 19.

(66) 5602 sayılı mülga Tapulama Kanununun 35 inci ve 36 ncı maddelerinde de arazî işleriyle ilgili sayılabilecek yetki kaideleri konulmuștu. Bir Yargıtay kararına göre «yargılamanın intizamı âmme sebebiyle ancak gayrımenkulün bulunduğu köyde icrası lâzımdır. Nizalı gayrımenkul ile alâkası olmayan köye davet ve burada muhakeme yaplamaz» (7. HD 11.3.1954, 8027/1869 «AD. 1954, 9/1156»).

(67) 31.8.1956 tarih ve $6830 \mathrm{SK}$ (RG 8.9.1956, S. 9402).

(68) Aslında istimlâk bedeli ile ilgili dâvalar birer alacak dâvasıdırlar. Yani uyuşmazlığın dolaysız müddeabihi burada bir para alacağıdır. Bu alacağ 1 doğuran istimlâk ameliyesi ise dâvanın dolaylı şekilde konusunu teşkil etmektedir. Bu durum karşısında (karş.dip not 47 ve civarı) istimlâk bedeline ilişkin uyuşmazliklarda yetkili mahkemenin 13 üncü maddeye göre tayin edileceği tarzında kanunì bir mecburiyetin bulunmaması gayeye daha uygun olurdu (karş. 4. HD 16.10.1964, 8440/4900 «Ersoy, Notlu -Izahlı- Içtihatlı Hukuk Usulü Muhakemeleri Kanunu, Ankara 1966, m. 13 s. 35»). Nitekim Alman Usûl Kanunu bu gibi dâvaları gayrımenkul mahkemesinin kesin yetkisine ( $\$ 24)$ tabî kılmamış, sadece bu mahkemenin ihtiyarî yetkisini kabul etmekle yetinmiştir ( $\$ 26$ ).

(69) 4. HD 29.2.1944, 110/658 (Atasayan, age. m. 13 s. 112); 1944 Y.K./ 103 (Karaok, age. m. 13 No. 4). 
Son olarak Kadastro ve Tapu Tahriri Banununun (70) $27 \mathrm{ncj}$ maddesi (71) ile Kadastro ve Tapu Tahriri Nizamnamesinin (72) $6 \mathrm{ncı}$ maddesinde de gayrımenkullere ilişkin uyuşmazlıkların çözümlenmesi konusunda yetkiyi belirten hükümler yer almıştır.

Gayrımerkulün aynı hakkındaki dâvalar bölümünü bitirmeden önce, miras münasebetiyle çıkan gayrımenkule ilișkin iddiaların nerede görülmesi gerekeceği hususuna da değinmek faydalı olacaktır. Bir fikre göre (73) bu gibi iddiaların ve bunlardan bilhassa miras münasebetiyle gayrımenkullerin taksimi iddiasının, HUMK" nun 11 inci maddesinin tercihan tatbiki suretiyle ve mirasta vahdeti sağlamak gayesiyle mirasın açıldığı yer mahkemesinde görülmesi gerekmektedir. Kanaatimizce gayrmmenkulün aynına ilişkin dâvaların bunlar miras sebebiyle açılmış olsalar bile, yine 13 üncu maddenin kesin yetkisine girmesi icap eder. Zira miras işlerinde kesin yetkiyi düzenleyen HUMK $\mathrm{m}$. 11/I bu dâvalarm neler olabileceğini tahdidî olarak saymış olup gayrımenkullerin ayınlarına ilişkin iddialar bu meyanda zikredilmemiştir. Aksine bu dâvalar genellikle terekeyi bir kül olarak ilgilendiren cinsten olurlarsa an. cak bir dereceye kadar 11 inci maddenin kapsamma girebilmelidirler. Kaldı ki, maddenin ikinci fıkrasında açıkça «terekeden bir mal hakkında istihkak dâvası terekenin tahrir ve tesbiti zamanında mal nerede bulunur ise orada dahi ikame olunabilir» denilmek suretiyle aynî karakterdeki dâvalar bakımından birinci fıkradaki kesin yetki kaidesine bir istisna kabul edilmiş bulunmaktadır. Hal böyle olunca 13 üncü maddenin kesin yetkisine mutlak surette tâbi olan topyekûn gayrımenkul ayın dâvaları bakımından da aynı istisnanın öncelikle cari olacağl gayet tabiîdir. Şu halde konusu itibariyle doğrudan doğruya gayrımenkulün aynıyla ilgili olan bir dâvanın miras sebebiyle veya diğer bir saikle doğmuş olması bura.* da ehemmiyeti haiz olmamalıdır (73a).

(70) 11.12.1934 tarih ve 2613 SK.

(71) Bu maddede adı geçen ve aynı kanunun 12 nci maddesi ile kurulan Kadastro Mahkemeleri daha sonra 5572 SK'un 2 nci maddesi ile kaldırılmış ve bunların işleri asliye mahkemelerine devredilmiştir.

(72) Niz. No. 2/3642, 2.12.1935.

(73) Stein-Jonas, age. $\S 24$ III 1; Belgesay, age. m. 13 No. 2.

(73a) 23 Şubat 1330 tarihli Muvakkat Kanunun (Memaliki Osmaniyede mukim tebaayı ecnebiyenin hukuk ve vezaifi hakkında kanunu muvakkat) 4 üncü maddesinin gayrımenkullere dair olan hükmü, 
b) G a y r imenkul üzerinde bir hak $\mathrm{ka}$ i 1 iş k i n ol a d âval a r

HUMK m. 13/II de gayrımenkulün aynına ilişkin olan dảvalardan başka, o gayrımenkul üzerinde bir hakka dair olan dâvaların da gayrımenkule müteallik dâvalardan oldukları ve netice itibariyle bu gibi dâvaların da söz konusu gayrımenkulün bulunduğu yer mahkemesinde açılacakları (f. I) hükme bağlanmıştır. «Gayrımenkul üzerindeki bir hak» terimi pek açık değildir. Bu vuzuhsuzluk daha çok o hakkın mahiyeti bakımından bahis konusu olur. Kanunun lâfzından bu hakların gerek aynî gerek şahsî karakterde olabileceği gibi bir anlam çıkarılmaktadır (74). Nitekim mehaz kanunun kanunumuzun 13 üncü maddesini karşlayan 11 inci maddesinde «Aynî olsun, şahsî olsun gayrımenkule ilişkin bütün dâvalar» denilmektedir. Kanunumuza bu ibarenin aynen alınmamasinm ne gibi bir sebebe dayandığ 1 hakkında birşey söylemek mümkün değildir. Zira gerek gerekçede ve komisyon zabitlarıncla gerekse tasarının umumi heyette pek acele ve kisa olarak yapılmış olan görüşmelerine ait tutanak bölümlerinde bu cihete değinilmemiştir. Ifadedeki bu vuzuhsuzluk doktrinde çeşitli fikirlerin ileri sürülmesine sebep olmuştur. Bir fikre göre (75) «Gayrımenkul üzerinde hak sözü aynî hakka mukabil zikredildiğinden, gayrımenkul üzerinde şahsî hakları ifade eder». Bu görüş pek kabule şayan olmasa gerektir. Diğer bir fikir (76) «Kanunun, iddianın gayrımenkul üzerinde bir hakka taallûkunu kâfi görmekte olup, bunun aynî hak olması şartını dahi aramadığı» şeklindedir. Biz bu görüşü de tereddütle karşllıyacağız. Nihayet son bir fikir (77) «Gayrımenkul üzerinde bir hak» ibaresinin sadece aynî haklara münhasır olacağı yönünde-

HUMK m. 13 ün kapsamını, son ikametgâhı yabancı memlekette olan müteveffanın terekesine dahil olan Türkiye'deki gayrımenkulleri hakkındaki tereke dâvalarını da içine alacak şekilde genișletmektedir (Seviğ, Ticarî Sahadaki Kanunlar İhtilafı, İstanbul 1958, s. 47 ; bk. ayrıca Berki, Devletler Hususî Hukuku c. 2. -Kanun İhtilâflar1-, 6. Bas1, Ankara 1966, s. 47, 249-250). Öte yandan Devletler Hususî Hukuku sahasında bazı memleketler (Ingiltere, Isviçre, Fransa) gayrımenkuller üzerindeki miras hukukunu doğrudan doğruya lex rei sitae’ye tâbî kılmışlardır (Seviğg, age. s. 45).

(74) Karş. Bilge, MYH s. 176; Kuru, HMU s. 114.

(75) Belgesay, age. m. $13 \mathrm{I} \mathrm{b}, \mathrm{s} .48$.

(76) Postacıŏlu, age. s. 116 .

(77) Karafakih, age. s. 65 ; Bilge, MYH s. 176 ; Kuru HMU s. 114. 
dir. Bizce en isabetli olan bu son görüştür. Çünkü m. 13 ün kesir yetkisini gerektiren en mühim faktör, «aynîlik» vasfı gayrımenkullere ilişkin şahsî haklarda mevcut değildir; dolayısıyla bu gibi dâvalar, aksine sözleşme (HUMK m.22) yapllmamişsa m. 9 un genel yetkisine tâbî olurlar. Kaldı ki, Yargıtayın görüșü de bu son fikir istikametinde gelişmiştir (78).

Gayrımenkuller üzerindeki aynî haklar Medenî Kanunun 4 üncü kitabı olan «Aynî Haklar» bölümünde düzenlenmiștir. Bu haklar bilindiği üzere irtifak hakları, gayrımenkul mükellefiyeti ve rehin hakkı olmak üzere üç ana kategoriye ayrılırlar. Bu aynî hakların her birisine ilişkin olabilecek dâvalar bakımından yetkili mahkemeyi bunları ayrı ayrı incelemek suretiyle belirtelim:

a) I r t f a k ha k l a r $\mathrm{rnd}$ a ye t k i

13 üncü maddenin ikinci fıkrasında zikredilen «gayrımenkui üzerindeki (aynî) hak» sözüyle akla ilk olarak irtifak hakları (MK. m. 703 vd.) gelir. Írtifak hakları da kendi aralarında aynî irtifak hakları, șahsî irtifak hakları ve muhtelit irtifak hakları olmak üzere siniflandirilırlar (79).

Aynî irtifak hakları (MK. m. 703 - 716) ancak bir gayrımenkıı üzerine diğer bir gayrımenkul lehine yüklenen külfetlerdir (MK m. 703/I). Şu halde aynî irtifakta daima iki gayrımenkul ve ekseriya iki ayrı şahıs (80) vardır. İrtifak hakkından istifade eden şahıs hakim gayrımenkul maliki, irtifak hakkı borçlusu şahıs ise hâdim gayrımenkul sahibidir. Gayrımenkuller üzerindeki aynî haklardan irtifak hakları için 13 üncü maddede yetkiye ilișkin bir hüküm konulmuştur. Bu hükme göre, «Irtifak haklarına dair iddialarcla, üzerine irtifak hakkı taallûk eden malın bulunduğu mahal mahkemesi salâhiyettardır» (f. II C. 2) (81). Bütün irtifak haklarina şâmil olabilecek genişlikte olan bu hüküm, aynî irtifaklar bakı. mindan da gayet açıktır. Şu halde aynî irtifak hakları dolayısıylı çıkan uyuşmazlıklar daima yükümlü gayrımenkulün bulunduğı

(78) Bk. dip not $137-162$ civarl.

(79) Karş. Saymen-Elbir, age. s. $440-441$.

(80) Gayrımenkullerin başka bașka olmasına rağmen maliklerin tek kişiden ibaret bulunması da mümkündür (MK m. 706).

(81) Kars. Leuch, Art. 29 No. 4; ZPO \$ 24/II; 4. HD 19.12.1940 (Demirhan-Tazebay, age. m. 13 No. 1348). 
ver mahkemesinde görülecek, hakim gayrımenkul mahkemesi burada hiçbir zaman yetkili olmıyacaktır. Hükmün bu şekilde olması gayet mantıkidir. Zira aynî irtifak borçlusu hâdim gayrımenkul olduğundan, uyuşmazlık kaynağı genellikle bu gayrımenkul olacak ve bunun sonucu olarak da dâvanın asıl müddeabihini bu gayr:menkul teşkil edecektir.

Şahsî irtifak hakları (MK. m. 717 vd.) da 13 üncü maddede bahsedilen gayrımenkul üzerindeki (aynî) hak sözü içine gịrerler. $\mathrm{Bu}$ irtifaklar gayrımenkuller üzerindeki intifa hakkı (MK m. 717 739, özellikle m. $740-743$ ) ile sükna hakkmdan (MK m. 748-750) ibarettir. İşte bu haklar dolayısıyla çıkmış bulunan ayne ilişkin uyuşmazlıklar (82) için yetkili mahkemenin yine üzerinde intifa veya sükna hakkı tesis edilen gayrımenkulün bulunduğu yer mahkemesi olmasi gerekir (HUMK m. 13/II C. 1 ve 2) (83).

Aynî ve şahsî irtifak haklarından başka son olarak bir de muhtelit karakterdeki irtifak hakları vardır. Bu irtifak haklarından kanunda «Diğer irtifak hakları» başlığı altında genel olarak bahsedilmiștir (MK m. 753). Bu gruba mürur hakkı (MK m. 671-672), üst hakkı (MK m. 652) ve kaynak irtifak hakkı (MK m. 679) dahil edilebilir (84). Bütün bu irtifak hakkı nev'ilerinde de irtifak hakkı konusu olan gayrımenkulün veya mütemmim cüz'ün (dolayısıyla aslî şey olan gayrımenkulün) bulundukları yerin mahkemesi yetkili olacaktır (HUMK m. 13/II).

Nihayet 13 üncü maddenin kapsamina girecek aynî haklar ka. tegorisine tapu siciline şerh verilen şuf'a iştira ve vefa haklarıni da (MK. m. 658, 660) (85) sokabiliriz.

(82) Bu irtifak haklarının kullanılması ancak gayrımenkul üzerinde zilyedlik tesisi suretiyle kabil olabilecektir. Bu itibarla burada ihtilafın intifa veya sükna hakkıyla zilyedliğe ilişkin olması meselesini (hernekadar gayrımenkul mahkemesinin yetkisi üzerinde etkili değilse de) birbirinden ayırmak gerekir.

(83) Meselâ mer'a, yaylak ve kışlak dâvaları o yer üzerindeki intifa hakkına ilişkin oldukları için, bu gibi dâvaların mer'anın, yaylak veya kışlakın bulunduğu yer mahkemesinde açılması ve görülmesi gerekir (bk. Akgün, Mer'a hukuku, AD 1953 S. I, s. 3).

(84) Karş. Saymen-Elbir, age. s. 442, 495 vd.; Velidedeoğlu-Esmer, Gayrımenkul tasarrufları ve Tapu Sicili tatbikatı, 2. bası, İstanbul 1956, s. $340 \mathrm{vd}$.

(85) Bk. von der Crone, age. s. 39, 40, 56; karş. Tapulama Kanunu, m. $47 /$ I. 
bb) Gay r $1 \mathrm{menkul}$ m ükellefiy e tinde yet$\mathrm{k} \mathrm{i}$

Gayrımenkul mükellefiyeti (86), bir gayrımenkul malikinin mülkü dolayısıyla, o gayrımenkul karşıllk olmak üzere diğer bir kimse lehine bir şey vermeye veya yapmaya mecbur tutulmasıdrr (MK m. 754/I). Bu mükellefiyet diğer bir gayrımenkule malik olan kimse lehine de mülkiyeti dolayısıyla tesis olunabilir (f. II). Gayrımenkuller üzerinde tesis edilen bu hakkın aynîlik karakteri irtifak haklarında olduğu kadar kuvvetli olmamakla beraber, az sonra incelenecek rehin haklarında olduğundan daha fazladır. Bu itibarla gayrımenkul mükellefiyetinin irtifak ve rehin hakları arasında mutavassit bir yer işgal ettiği kabul olunmaktadır (87). Bu hak, sahibine irtifak haklarında olduğu gibi mükellef kılınan gayrımenkulden doğrudan doğruya bir istifadeyi mümkün kılmaz, ancak bazı edimlerin mükellef tarafından ifası hususunda bir alacak doğırur (88). Fakat bu hak mükellefe karşı hiçbir zaman şahsî karakterde bir alacak doğurmaz (MK m. 763/1), mükellef sadece bir gayrımenkulün malikidir diye diğer bir kimsenin meselà tarlasm sürmeye, ağaçlarına bakmaya, fabrikası için arazisinden ham madde vermeye vs. mecbur olur (89). Keza bir bataklığı kurutan şahıs kuruttuğu topraklar üzerinde gerekli bazı onarım, bakım ve temizleme işlerini yapmakla mükelleftir $(90)$. Bu misâllerden de anlaşllacağı üzere gayrımenkul mükellefiyeti edim ifa edildikçe adetá bir irtifak hakkına benzemektedir (91). Edimin ifa edilmemesi halinde ise. gayrimenkul mükellefiyeti irtifaktan ziyade gayrımen-

(86) Gayrmenkul mükellefiyeti genel olarak üç türlü mevzua sahip olabilir. Bunlar ya hakim gayrımenkuler için belli bir takım hizmetlerin ifası, yahut hâdim gayrımenkulün tabî̀ semerelerinin ve hasllatının hâkim gayrımenkul veya maliki lehine teslimi, yahut da hâdim gayrımenkulün iradından bazı nakdî edimlerin ödenmesi şeklinde olabilir (karş. Göktürk, age. s. 1015).

(87) Saymon -Elbir, age. s. 505; Göktürk, age. s. 1010; Wieland'a göre de gavrımenkul mükellefiyeti ne doğrudan doğruya aynî, ne de şahsi bir haktır (Kanunu Medenîde Aynî Haklar «Çev. Karafakı», 2. basi. Ankara 1946, m. 7823 b).

(88) Bu alacak takyit edilen gayrmenkulün malikinin değişmesi takdirinde, yeni malik aleyhine de aynen mevcut olur (MK m. 764).

(89) Misaller için bk. Saymen -Elbir, age. s. 502; Velidedeoğlu -Esmer, age. s. 305; Wieland «Karafak1», age. m. 782 No. 1.

(90) Bk. "Bataklikların kurutulması ve bundan elde edilecek topraklar hakkinda kanun» No. 5516, 18.1.1950 (RG 23.1.1950, S. 7413), m. 9. 
kul rehnine yaklaşır (91) ve aynîlik karakteri biraz zayıflar gibi görünür. Zira edimin yerine getirilmesi halinde istifade eden şahıs gayrımenkulün kıymeti üzerinden hakkını elde etmek yetkisini kazanır (MK m. 763 C. 1). Yani bu halde gayrımenkul mükellefiyeti haklısı, mükellef gayrımenkulü tıpkı gayrımenkul rehninde olduğu gibi sattırarak satış bedelinden alacağını almak yetkisini haiz olur. Fakat burada gayrimenkul rehninden farkl olarak bu mükellefiyetin (borcun) menşei taraflar arasındaki şahsî karakterde bir akde (mes. alım-satım) değil, bilâkis gayrımenkul mükellefiyeti gibi aynî bir münasebete dayanır. Hal böyle olunca gayrımenkul mükellefiyetinin, tesisi, sukutu vb. gibi yönlerinden gayri, konusu itibariyle de tamamen aynî hak özelliğinde olduğu kendil:ğinden ortaya çıkar (92). Bunun tabiî sonucu ise gayrımenkul mükellefiyetine ilişkin her türlü dâvanın HUMK m. 13 gereğince ilgili gayrımenkulün bulunduğu yer mahkemesinin mutlak yetkisine tabî bulunması olacaktır (93) (94).

c) G a y r m e n kul re hni nde ye t k i

Türk Hukukunda, aynî haklardan olan gayrımenkul rehni (MK m. $765 \mathrm{vd}$ ) (95) ipotek (MK. m. 796 -811), ipotekli borç senedi (MK m. 812-816, $823-843$ ) veya irad senedi (MK. m. 817-822, 823 - 843) şeklinde tesis olunabilir. Ípotek ile gayrımenkul, bir borç için teminat olarak gösterilir. $\mathrm{Bu}$ bir aynî teminattır (aynî hak), fakat bununla temin edilmek istenilen borç şahsî bir borçtur. İpotekli borç senedi ve irad senedi ise birer kıymetli évrak vasfını taşırlar ve yine şahsî bir borcun temini gayesiyle bir gayrımenkulün

(91) Karş. Saymen - Elbir, age. s. 505; Göktürk, age. s. 1011 b.

(92) Gayrımenkul mükellefiyetinin konusunun şahsî borç olabileceği (MK m. 763 C. 2), dolayısıyla bunun mevzuunun aynîlik vasfının sona erebileceği istisnaî hal için bk. dip not 158 ve 159 civarı.

(93) Aynı fikirde: Leuch, age. Art. 29 No. 1. Bu müellife göre, aynî bir vecibenin ifası, meselâ gayrımenkul mükellefiyeti ve irad senedinden mütevellit edalar dolayısıyla açılacak dâvalar için gayrımenkulün bulunduğu yer mahkemesinin yetkili olması gerekir. Karş. ayrica von der Crone, age. s. $34-3 \overline{5}$.

(94) Gayrımenkul mükellefiyeti başka bir gayrımenkul maliki lehine mülkü dolayısıyla tesis edilmişse (MK m. 754/II), yetkili mahkeme HUMK m. 13/II C. 2 de olduğu gibi hâdim gayrımenkulün bulunduğu yer mahkemesi olmalıdır.

(95) Bk. Wieland «Karafakı», age. m. 793; Velidedeoğlu -Esmer, age. s. 364; Saymen - Elbir, age. s. 518. 
tahsisini istihdaf ederler (96). Yanliz burada ipotek ve ipotekli borç senedi ile irad senedi arasındaki şu farkı belirtmek gerekir. Birincilerde şahsî mesuliyet (MK. m. 796, 812) bahse konu olduğu halde, irad senedindeki mesuliyet aynî karakterdedir (MK m. 817/ II); söyle ki. borcunu elde edemiyen alacaklı alacağını yanlız ipotek veya ipotekli borç senedi mevzuu olan gayrımenkulden elde etmekle kalmaz, aksine borçlunun bu gayrımenkul dışında kalan mamelekine de müracaat edebilir. Halbuki irad serıedinde alacaklı alacağını sadece rehne konu teşkil eden gayrımenkul üzerinden alabilir, borçlunun diğger mallarına gidemez (97).

$\mathrm{Bu}$ izahattan da anlaşlacağı üzere, gayrımenkul rehin nev'ileri yani ipotek, ipotekli borç senedi ve irad senedi ile temin edilmis, olan alacağın mahiyeti bir tarafa bırakılacak olursa, her üç rehin şekli de hukukî bünyeleri itibariyle tamamen aynî karakterde olan haklardır. Hal böyle olunca alacak hak ve münasebeti dışında kalıp da bu aynî hakların tesis edilmeleri (98), tapuya tescilleri, son bulmaları gibi tamamen müessesenin kendi bünyesine has sorunların da yine bu alacak hakkından soyutlanmış olarak göz önüne alınması gerekecektir. Bir aynî hakkın tesisi, sukutu vb. gibi muameleler ise zarurî olarak aynî işlemler olacağından, bunlar dolayısıyla çıkmış bulunan uyuşmazlıkların çözümlenmesi için başvurulacak mahkemenin de Usûl Kanununun 13 üncü maddesinin emredici hükmüne göre tayin edilmesi ve netice itibariyle gayrımenkul rehnine ilişkin bu gibi dâvaların ilgili gayrımenkul mahkemesinin kesin yetkisine tabî olması gerekecektir (99). Şu halde diğer aynî haklardan doğan uyuşmazlıklar sebebiyle açılmış olan dâvalarda olduğu gibi, yetkili yargı merciinin, üzerinde rehin hakkı tesis edilen gayrımenkulün bulunduğu yer mahkemesi olacağı hususunda tereddüt kalmayacaktır.

(96) Bk. Saymen - Elbir, age. s. 516-517; Velidedeoğlu -Esmer, age. s. 387, 401; Göktürk, age. s. $1024-1025$.

(97) Saymen -Elbir, age. s. 517; Velidedeoğlu -Esmer, age. s. 402; Göktürk, age. s. 1025 .

(98) Ípoteğin tesisi Wieczorek'e göre (age. \$ $25 \mathrm{~B}$ ) tamamen Borçlar Hukuku karakterinde bir işlemdir; bu bakımdan gayrımenkul mahkemesinin kesin yetkisi dışında kalır.

(99) Aynı fikirde: Belgesay, age. $\$ 131$ a; von der Crone bu konuda Fransiz Hukukuna uygun olarak alternatif yetkiyi (gayrimenkul veya ikametgâh mahkemesi) kabul etmektedir (age. s. $40-41$ ). 
Bunun yanı sıra, ipotek ve ipotekli borç senedinde olduğunun aksine irad senedinde, irad senedinin yanlız hukukî bünyesinden doğan uyuşmazlıklar bakımından değil, fakat bu rehin müessesesi ile temin edilmiş olan alacak dolayısıyla çıkacak uyuşmazlıklar bakımından da 13 üncü maddenin mutlak yetkisini kabul etmek uygun olacaktır. Zira kanunumuzda da belirtildiği üzere irad senedi, bir gayrımenkul üzerinde gayrımenkul mükellefiyeti olarak tesis olunan bir alacaktır (MK. m. 817/I).

İrad senedi şahsî bir borç tevlit etmez ve alacă̆ın cihetini de ihtiva etmez (f. 3). Bu durum karşısında tıpkı gayrımenkul mükellefiyetinde olduğu gibi, irad senedi ile takyit edilmiş olan gayrımenkulün kıymeti bu senetdeki borcu karşılayamazsa, kalan kısım için - ipotek ve ipotekli borç senedinde olduğu gibi - borçlunun şahsına müracaat edilmiyecektir. Zira burada borçlu olan şahıs değil gavrımenkuldür. Şu halde buradaki alacak da tamamen aynî karakterdedir; adeta aynî bir haktır (100). Bunun normal neticesi ise, irad senedi ile temin edilmiş bulunan alacakla ilgili olarak açı. lacak dâvaların da HUMK m. 13'e uygun şekilde gayrımenkulün bulunduğu yer mahkemesinde açılması olacaktır (101).

c) G a y r l m e n k u ün zilyed liğine ilişkin d â $v$ a l a r

Gayrımenkuller üzerindeki zilyedlikten doğan dâvalar da 13 üncü maddenin ikinci fıkrası anlamında gayrımenkule ilişkin dâva addolunurlar. $\mathrm{Bu}$, zilyedliğin aynî hak olmasının tabiî bir sonucudur (102). Usûl Kanunumuz zilyedlik dâvalarının 13 üncü maddenin kapsamına girmesi bakımmdan zilyedliğin devamlı veya geçici olması arasında bir fark gözetmemiştir. Nitekim ikinci fikranın «Gayrımenkule müteallik dâva ..... muvakkat olsa bile anın zilyedliğine ..... mütedair olanlardır» şeklindeki ifadesi bu konuda sarihtir ve maddenin mehazdaki sekline de uygundur (103).

Bilindiği gibi zilyedlik, bir şey üzerinde fiilen tasarruf edebilme iktidarını (MK m. 887 C. 1) (104) ifade eder. Şu halde zilyedli-

(100) Bk. Velidedeoğlu -Esmer, age. s. 402.

(101) Aynı fikirde: Leuch, age. Art. 29 No. 1; bk. dip not 93.

(102) Zilyedliğin müessese olarak Medenî Kanunun Aynî Haklar bölümünde yer almış olması da buna delil teşkil eder (ḱarş. Velidedeoğlu -Esmer, age. s. 577 - 578).

(103) Bk. CPCN Art. 11/II. 
ğin konusu, fiilî tasarruf yetkisi bahşeden bir ayni haktan ibarettir (105). Zilyedlik ile bu aynî hak arasında varlığ1 farz olunan karine gayrımenkul zilyedliğinde menkul zilyedliğinde olduğundan başka esaslara dayanır. Zilyedlik menkul mallarda mülkiyete karinedir ( $M K$ m. 898, 899). Halbuki gayrımenkullerde zilyedlik mülkiyetin karinesi değildir. Gayrımenkullerde mülkiyet karinesini tapu sicilindeki kayıt teşkil eder (MK. m. 905 C. 1) (106). Nitekirn bu madde hükmüne göre «Tapu siciline kaydedilmiş olan gayrımenkuller için hak karinesine istinat etmek ve zilyedlik dâvaları ikame eylemek salâhiyeti, ancak kendi lehine tescil vaki olan kimseye ait olur». Şu halde gayrımenkulün zilyedi hakkını sicilde lehine kayıt bulunan şahıstan iktisap etse bile tapu sicilinde kayıtlı bulunmadıkça - sırf kendi zilyedliğine dayanarak-zilyedlik iddiasinda bulunamaz. Binaenaleyh maddedeki dâva sözünden sadece tescilin ifade ettiği dı̧̧ görünüşe dayanarak ve aynî bir hak, mülkiyet hakkı veya diğer bir hakkı ileri sürerek açılan dâva anlaşılmälidır (107).

13 üncü maddenin ikinci flkrasında söz konusu edilen zilyedlik dâvaları bakımından bizi asıl ilgilendirecek olan husus yine MK m. 905'in ikinci cümlesi hükmüdür. Bu hükümde «Bununla beraber gayrımenkul bilfiil kendi iktidarı dahilinde bulunan kimse, gasp ve tecavüz sebebi ile dâva ikame edebilir» denilmektedir. Maddenin şu ifade tarzmndan da anlaşllacağı gibi, zilyed tamamen zilyedlik durumuna dayanarak, yani tapu sicilinde lehine bir kayıt bulunmasına lüzum olmaksızın zilyedlikten doğan dâvaları açabilecektir (108). Gayrımenkul zilyedinin açabileceği bu dâvalar ye. din iadesi dâvası ( $M K$ m. 895) ve tecavüzün men'i dâvasıdır (MK. m. 896) (109).

(104) ZGB Art. 919; karş. BGB \$ 854.

(105) Bu hakkı haiz olan kimsenin zilyedliği aslen veya devren iktisap etmiş olmasının HUMK m. 13 bakımından hiçbir önemi yoktur.

(106) Bk. IBK 9.10.1946, 6/12 (RG 20.6.1947, S. 6637).

(107) Wieland «Karafakı», age. s. $830-831$.

(108) Esasen 13 üncü maddedeki zilyedlik sözüyle münhasiran zilyedliğin korunmasina ilişkin dâvalar (MK m. 895, 896) hedef tutulmuştur (bk. HGK 30.1.1963, 6-27/5).

(109) Karş. von der Crone, age. s. 33, 42, 58, 59. Gayrimenkul zilyedinin bu dâvalardan başka o gayrımenkule yapılan gasp ve tecavüz fiillerini MK m. 894'e göre kuvvet kullanarak def'etmek hakkı da saklıdır. Bu konuyla ilgili olarak bk: «Gayrımenkule tecavüzün def'i hakkinda kanun» No. 5917, 16.4.1952 (RG 24.4.1952, S. 8093). 
Bu dâvaları açabilmesi için zilyedin mutlaka malik sıfatını da haiz olması icap etmez. Şu halde fer'i zilyed olan kimse dahi bu dâvaları açabilecektir (110). Demek oluyor ki, tapu siciline kaydedilmiş olan gayrımenkullerin zilyedliğine ilişkin olarak açılabilecek olan dâvalar esas itibariyle zilyedliğin himayesine dair olup MK m. 895 ve 896 da tanzim edilmiş bulunanlardır. Malik sıfatını haiz olmayan zilyedin, o gayrımenkul üzerindeki zilyedliği dolayısıyla açacağ1 bu dâvalar için yetkili mahkeme, HUMK m. 13/II muvacehesinde, gayrımenkulün bulunduğu yer mahkemesi olacaktır.

Öte yandan Türk Hukukunda zilyedlik dâvaları, tapuya kayıtlı bulunmayan gayrımenkuller (110a) üzerindeki zilyedlik hakkınin korunması bakımından dia ehemmiyeti haizdirler. Fakat bu gibi gayrimenkuller üzerindeki zilyedliğin, tapu siciline kayıtlı olan gayrımenkullerdeki zilyedliğe nazaran hukukî bakımdan bazı farklı tarafları olabilir. Şöyle ki, tapuya kayıtlı olmayan gayrımenkul. lerdeki zilyedlik hakka karine teşkil edebilir. Bi sebepten bu gibi gayrımenkullerin menkul dâvasına konu teşkil etmeleri de - bunkarın tabî̂ durumlarına uygun geldiŏi nisbette - mümkündür (111).

Yargitay tapu siciline kayıtı olmayan gayrımenkullerin zilyedliğinin gasbedilmesi halinde, fevkalâde müruruzaman yoluyla iktisap için gerekli şartların (MK. m. 639) mevcut olması kaydıyla, evvelki zilyed lehine menkui zilyedliği hakkındaki MK m. 902 ve 904 hükümlerinin uygulanabileceği görüşündedir (112).

Görülüyor ki zilyedlik dâvaları bakımındarı tapuda kayıtlı clmayan gayrımenkullere, himaye yönünden tabî olunacak hükümler bakımından, kayıtlı bulunanlara nazaran daha geniș bir saha tanınmıştır. Burada, tapuda kayıtlı bulunmayan gayrımenkuller hakkındaki zilyedlik dâvalarınin menkul zilyedlị̆gine dair dâvalara konu teşkil ediyor olması dolayısıyla, bu gibi gayrımenkuller üzerindeki zilyedliğe ilişkin dàvalarda yetki meselesinin HUMK m.

(110) Bk. Velidedeoğlu - Esmer, age. s. 274.

(110a) Türk Hukukunda tapuya kayıtı bulunmayan gayrımenkuller için bk. Acemoğlu, Türk Hukukunda tapu kütüğüne kayitlı olmayan gayrımenkullerin hukukî durumu, İstanbul 1965.

(111) Akipek, age. s. 218.

(112) Bk. Reisoğlu, Türk Eşya Hukuku I, Anǐara 1965, s. 66. Yargıtayın bu konudaki görüşünü belirtmek için bu müellifçe şu kararlar zikredilmektedir: HGK 6.3.1963 ve 3.6.1964; 1. HD. 25.1.1954. 
13'e göre tanzim edilmesinin zorunlu olmadığ1 şeklinde bir düşünce akla gelebilir. Fakat böyle bir görüş tamamen hatalı olur. Zirı buradaki zilyedlik dâvasının isminin, hukukî mahiyetinin ve tabî bulunduğu hükümlerin değişmesi, bizatihi zilyedlik üzerinde etkili olan ve onun maddî yönünü değiştiren unsurlar değildirler. Bahis konusu zilyedlik yine bir gayrımenkul zilyedliği, gayrımenkule ilişkin aynî bir hak olma vasfını muhafaza eder. Şu halde gayrımenkul ayın dâvalarında hakim unsur olan kamu düzeni düşüncesi burada da normal olarak bahis konusu olacak ve bunun tabîi bir sonucu olarak da dâvanın gayrımenkulün bulunduğu yer mahkemesinde görülmesi icap edecektir (112a).

Bazen bir gayrımenkulün kendisi değil fakat mütemmim cüz'leri üzerinde bağımsız olarak zilyedlik tesis olunabilir. Bu mütemmim cüz'ler meselâ bir evin bir aynî hakka müstakil olarak konu teşkil etmeyen çatısı, pencereleri veya ilân için kiraya verilmiş dış duvarları olabilir. Keza bir evin müstakil mülkiyete konu olmayan daireleri ve odaları üzerinde de zilyedlik kurulabilir (113). Bir gayrımenkulün mütemmim cüz'leri addedilen bu gibi kısımları ̈̈zerindeki zilyedlik dolayısıyla bu zilyedliğe ilişkin olarak çıkabilecek olan uyuşmazlıkların da 13 üncü maddeye uygun şekilde giderilmesi zarurî olacaktır. Şu halde mütemmim cüz'lerin ait olduğu gayrımenkulün (aslî şeyin) bulunduğu yerin mahkemesi bu konuda yetkili olacaktır.

MK m. 887 gayrımenkul üzerindeki haklara ilişkin olan bir zilyedliğe de imkân vermektedir. Bu zilyedlik ancak irtifak haklari ve gayrimenkul mükellefiyetinden mütevellit haklar üzerinde tesis edilebilecek (114) ve mahiyeti sadece bu hakların kullanılmasindan ibaret. olacaktır. Meselâ geçit hakkı, kaynak hakkı sahibi bu hakların zilyedidirler. Haklar üzerindeki zilyedlikde de gayrımenkuller üzerindeki zilyedlikde olduğu gibi zilyedliğin himayesi bahis konusu olur. Bu himaye burada da hakkın fiilen korunmais

(112a) Tapu kütügüne kayıtı bulunmayan gayrımenkullerin devri hakkındaki anlașmalar HUMK m. 13 ün kapsamına girerler (Acemoğlu, age. s. 64).

(113) Reisoğlu, age. s. 27; Saymen -Elbir, age. s. 50.

(114) Intifa, rehin, sükna hakkı gibi diğer haiklarda müstakil bir zilyedlik tesisi imkânsızdır. Çünkü bu hakların sahipleri esasen hakka konu teşkil eden şey (mes. gayrımenkul) üzerinde de zilyed durumunda bulunacaklardır (bk. Velidedeoğlu -Esmer, age. s. 275). 
veya zilyedliğge yapılan tecavüzlerden dolayı zilyedlik dâvaları açılması şeklinde ortaya çıkar (115). Irtifak hakkı ve gayrımenkul mükellefiyeti üzerindeki zilyedlikten dolayı açılacak zilyedlik dâvaları (MK m. 895, 896) için de, HUMK m. 13/II gereğince, bu haklara temel teşkil eden gayrımenkulün bulunduğu yer mahkemesinin yetkili olacağında şüphe yoktur.

d) Ga yrimenkuller üzerindeki hapis hakkına ilişkin dâvalar

Gayrımenkullerin aynına ilişkin dâvalardan sonuncusu olaraks 13 üncü maddenin ikinci fıkrasında gayrımenkulün hapis hakkına dair olanlar zikredilmektedir. Maddenin bu bölümü, üzerinde en çok tartışılan kısım olmuştur. Zira maddenin aslı olan Neuchatel Usûl Kanununun (CPCN) 11 inci maddesinde «droit à la détention» kavramı kullanılmıştır ki bu esas itibariyle «alıkoyma hakkı» nı ifade eder ve geçici olan bu hak meselâ alacağın ödenmesiyle nihayet bulur. Mehaz metindeki «détention» kelimesi kanunumuza aynen alınmamış ve «droit à la rètention» karşılığı olarak «hapis hakkı» şeklinde geçmiştir (116). Kanunumuzun gerekçesinde ve ilgili tutanak bölümlerinde bu hususa değinilmemiş olduğundan bu ayrıcalığın bir tercüme hatasının sonucu olabileceği akla yakın en kuvvetli ihtimal olarak ortaya çıkmaktadır. Bir fikre göre (117) bu tamamen tercüme hatasına dayanmaktadır, hapis hakkı kavramını aslında olduğu gibi «détention» karşllı̆̆ı olarak gayrımenkul üzerinde <iradesiz bir yer hakkı» olarak anlamak zorunluluğu kendisini göstermektedir; zira gayrımenkul üzerinde hapis hakkı tasavvuru kabil bir şey değildir. Diğer bir görüş (118) ise böyle bir hapis hakkının bazı şartlar altında pekalâ mümkün olabileceği istikametindedir.

Acaba gayrimenkuller üzerinde hakikaten bir hapis hakkı kabul edilebilir mi? Kabul edilebilirse bunun hukukî karakteri ne olmalıdır? Hapis hakkı müessesesi esas itibariyle MK m. 864 - 867 de tanzim edilmiş olup, mevzuunu sadece menkul şeyler ve kıymetli

(115) Bk. Velidedeoğlu -Esmer, age. s. 274-275; Wieland, age. s. 782, 808; Saymen -Elbir, age. s. $49-50$

(116) Umar -Alangoya, Açıklamalı Hukuk Usulü Muhakemeleri Kanunu, İstanbul 1964, m. 13 s. 22.

(117) Karafakih, age. s. 65.

(118) Ansay, age. s. 94. 
evrak teşkil eder (MK m. 864/I). «Umumî hapis hakkı diyebileceğimiz bu hapis hakkı muaccel olan bir alacağın tahsili için kullanılabilir (MK m. 864/I) ve paraya tahvil yetkisi bahşeder (MK m. $865,867 / \mathrm{I})$.

Buna karşlık hapis hakkının adetâ özel bir nev'ini teşkil eden, hüsniniyetli zilyedin (119) zilyedi bulunduğu mal üzerinde yapmış olduğu zarurî ve faydalı masraflardan dolayı haiz olduğu hapis (alıkoyma) hakkı (MK m. 907/I) (120), hem menkullerde hem de gayrımenkullerde bahis konusu olabilir (121). Hapis hakkının bu çeşidinde alacağın nakde çevrilmesi imkânsızdır, ayrıca muacceliyet şartı da aranmaz (122).

Kanunen tanınmış olan bu gayrımenkul hapis hakkından başka tatibkatta, sadece gayrımenkullere münhasır olmak üzere kabul edilen bir hapis hakkı çeşidi daha vardır ki, bu da haricen gayrımenkul satışlarında satış akdinin hükümsüzlüğü dolayısıyla ödenmiş olan satış bedelinin iadesini temine matuf bulunmaktadır. Yargıtay gayrımenkulün haricen satılması ralinde, gayrımenkulün hüsnüniyetli zilyedine bazen MK m. 907/l'e göre, yapılmış olan zarurî ve faydalı masrafların ödenmesine (123), fakat ekseri hallerde - gerek yanlız başına gerek masraflara ilişkin iddialarla birlikte . ödenmiş olan semenin satış akdinin hükümsüzlüğü dolayısıyla ken-

(119) MK m. 908'de belirtilmediğine göre suiniyetli zilyedin zarurî masraflardan dolayı gayrumenkul üzerinde hapis hakkı yoktur (karş. Cansel. Türk Hususî Hukukunda Hapis Hakkı, Ankara 1961, s. 170; İmre, Gayrımenkuller üzerinde hapis hakkı dermeyan edilebilir. mi?, IBD c. XXVI S. 3 s. $140-141$; Saymen -Elbir, age. s. 670) 10.6.1950 tarihli bir kararında Yargitay aksi fikirde bulunmuştur (5. HD $3403 / 1406 \ll b k$. İmre, agm. s. 132»).

(120) Zaruri ve faydalı masraflar dişında kalan sarfiyat (lüks masraflar) dolayısıyla hapis hakkı -MK m. 907 nin sarahati karşısında- bahis konusu olamaz.

(121) Cansel, age. s. $166-167$; Akipek, age. s. $242-243$; İmre. agm. s. $136-137$.

(122) Cansel, age. s. 170; Imre, agm. s. 142.

(123) 4. HD 7.11.1950, 5439/5295 ('Tat. Yg. Kar. S. 22, s. 627-628); HGK 15.9.1949, 1-83-44/54 (Tat. Yg. Kar. S. 4, s. 109); HGK 2.7.1949, $549 / 1830$ (ABD 1949 c. 5 S. 66, s. 24); 5. HD 31.3.1949, 3360/885 (AD 1949 S. 8, s. $1186-1187$ ); 1. HD 4. 10.1946, 6140/3920 (İBD S. 26 , s. 419$)$. 
disine iade edilmesine kadar (124) o gayrımenkul üzerinde bir hapis (alıkoyma) hakkı tanımaktadır. Ancak Yargitay bu konuda verdiği bir" kısım kararlarda masraflar bakımından hapis hakkını olduğu kadar bedelin iade edilmemesi sebebiyle hapis hakkını da MK m. 907/I'e istinat ettirir gözükmektedir (125). Halbuki 907 nci maddede açık olarak yanlız masraflardan (zarurî ve faydalı) söz. edilmiştir. Şu halde maddenin bu kesin ifadesi karşısında ve aynર̂ haklarda $\mathrm{n}$ u m e r u s c l a us u s prensibinin carî olması dolayısıyla yanlız masraftan bahseden mezkûr hükmün diğer hallere uygulanmaması gerekir (126). Bu itibarla bahis konusu Yargitay kararlarında haricen gayrımenkul satışlarının hükümsüzlüğü sebebiyle satış bedelinin iadesini temin zımnında o gayrımenkulün zilyedine (alıcısına) MK m. 907/I'e dayanarak hapis hakkı tanımanın isabet derecesi haklı olarak şüpheyi davet etmiş bulunmakta$\operatorname{dir}(126)$.

Haricen gayrimenkul satışlarında semenin iadesini sağlamak amacıyla kullanılan hapis hakkı Yargıtay'ın bir İçtihadı Birleştirme Kararında da (12ri) söz konusu edilmiştir. Bu karara göre «Tapusuz gayrımenkulün zilyedi tarafından haricen satılması ve teslimi kanun nazarında muteber olmadığından onun istirdatı talep ve dâva olunabilecek, ancak alıcının satıcıya verdiği bedeli ve ihtiyar ettiği masrafları alıncaya kadar gayrımenkul üzerinde bir hapis hakkı bulunacaktır». Bu içtihadı birleştirme kararında da satış bedeli masraflarla birlikte zikredildiği halde bunların hukukî dayanaklarının ne olduğu hususuna değinilmerniştir. Masraflar - bilin. diği üzere - MK m. 907/I'e istinat edecektir. Fakat semenin iadesi sebebiyle kullanılan hapis hakkının da bu içtihadı birleştirme ka-

(124) HGK 28.2.1958, 5-9/7 (TİK 19̄3 No. 223); HGK 11.1.1956, 1-2/2 (TIK 1956 No. 161); 7. HD 5.8.1954, 240/6185 (TÍK 1955 No. 190); HGK 4.2.1953, 1-152-4/11 (TIK 1954 No. 218); 5. HD 16.5.1950. $4487 / 4310$ - 10.6.1950, 3403/1406 - 27.7.1950, 3587/3300 - 31.7.1950, $4052 / 3738$ - 2.8.1950, 4543/3892 - 5.10.1950, 3368/3204 (Imre, agm. s. $130-133$ ); 1. HD 14.1.1949, 9461/222 (Tat. Yg. Kar. S. 1, s. 21-22); HGK 28.9.1949, 1-132-67/84 (lleri Huk. D. S. 55, s. 871); HGK 16.1.1946, 5-19-14/12 (AD 1949 S. 11, s. 1656-1657); 4. HD 2.9.1941, 2516/2191 (†z. BD S. 26, s. 449).

(125) Bk. dip not 124 deki Yargitay kararları.

(126) Cansel, age. s. 168; İmre, agm. s $139-140$.

(127) İBK 22.11.1944 No. 32 (İçtihadı Birleştirme Kararları «Hukuk kismi» 1930-1947, Ankara 1948, s. $183-186$ ). 
rarında 907 nci maddeye istinat ettirilmiş olduğu söylenemez. Zi:a kararın biraz yukarısında bu hapis hakkının hukukî dayanağı olarak daha eski tarihli diğer bir içtihadı birleștirme kararı (128) zikredilmektedir. $\mathrm{Bu}$ ikinci kararda bir gayrımenkul haricen satılıp bedeli satana ve gayrımenkul de alana teslim edildikten sonra âkitlerden birisinin teslim ve tesellüm hususundaki vecibelerini yerine getirmekten kaçınması halinde, satışın muteber olmaması dolayısıyla tarafların verdiklerini iade ile mükellef bulunacakları, ancak bir taraf vecibesini yerine getirmedikçe diger tarafın buna zorlanamıyacağı, şu halde satıcı bedeli iade etmedikçe alıcının gayrımenkulü hapsetmeye hakkı olacağı görüşü savunulmuştur. Görüldüğü üzre buradaki alıkoyma açıkça ademi ifa sebebine istinat ettirilmektedir. Haricen satışlarda gayrımenkulün alıkonmasının ademi ifa def'ine (BK. m. 81) dayanarak yapılması konusunda ise doktrin ile içtihat arasında herhangi bir fikir ayrılığ bulunmamaktadır. Zira doktrin gayrımenkullerin haricen satışları dolayısıyla yapılan alıkonmalarının birçok Yargitay kararlarının aksine ve şu son İçtihadı Birleştirme Kararına uygun olarak MK m. 907/I'e değil, BK $\mathrm{m}$. 81'e dayanarak yapilmasina taraftar bulunmakta$\operatorname{dir}(129)$.

Netice olarak diyebiliriz ki, 13 üncü maddenin ikinci fıkrasındaki hapis hakk1 kavramının kapsamına iyi niyetli zilyedin zilyedi bulunduğu gayrımenkul üzerinde yapmış olduğu zarurî ve faydalı masrafları elde etmek üzere MK m. 907/I'e göre haiz bulunduğu hapis hakkı ile, haricen gayrımenkul satışlarında satış akdinin hükümsüz kılınması dolayısıyla, alıcının ödemiş olduğu satış bedeli iade edilinceye kadar BK m. 81 gereğince kendisine düşen mükellefiyeti yerine getirmeme zımmında malı (gayrımenkulü) alıkoymak hakkı girecektir.

Bunlardan bilhassa MK m. 907/I'de hükme bağlanan gayr1* menkul hapis hakkı paraya çevirme yetkisi vermediğinden ve tam karakterli bir hapis hakkı olmaktan ziyade bir şeyi alıkoyma hakkı (130) tanıyan eksik yönlü bir hapis hakkı karakterinde oldu-

(128) İBK 10.7.1940 No. 77 (İçtihadı Birleştirme Kararları «Hukuk kısmi» $1930-1947$, s. $67-68$ ).

(129) Bk. Cansel, age. s. 168; Saymen -Elbir, age. s. $671-672$; Imre, agm. s. $139-140$.

(130) Das Zurückbehaltungsrecht (BGB \& 273). 
gundan buna «nakıs hapis hakkl» da denebilir (131). Hattâ bazı yazarlarca (132), burada kullanlan «hapis hakkl» (133) terimi bile yerinde görülmemektedir. Sadece gayrımenkulün iyi niyetli zilyedinin haiz olabileceği bu alıkoyma yetkisi aynî mahiyette bir haktır ve- netice itibarile o, bu hakkını adı geçen mal üzerinde hak iddia eden üçüncü şahıslara. dolayısıyla eşyanın iadesini talep eden şahsın iflâsı halinde iflâs masasına, keza malı haczetmek isteyen malikin alacaklılarına karşı da ileri sürebilir (134).

Son olarak şunu da belirtmek gerekir ki, HUMK m. 13/II'de bahsedilen alıkoyma (hapis) hakkının gayrımenkul malikinin MK m. 676/II'ye ve gayrımenkul kiralıyanın BK m. 267 -269'a göre haiz bulundukları hapis hakkı (135) ile en küçük bir ilgisi bulunmamaktadır. Zira adı geçen maddelerin tetkikinden de hemen anlaşılacaktır ki, bu hapis hakkı çeşitleri gerçi gayrımenkul maliklerinin ve kiralıyanlarının gayrımenkulleri dolayısıyla söz konusu olurlar; fakat bunlarda hapis hakkına konu olan mallar bizzat o gayrımenkuller olmayıp, bunların üzerinde veya içinde bulunan bazı menkul eşyadir.

\section{4) Gayrımenkullerle alâkalı dâvalardan HUMK m. 13 ün kap- samina girmeyenler}

$\mathrm{Bu}$ guruba - genel bir ifadeyle - gayrımenkulün aynına ilişkin olmayan dâvalar girerler. Bu dâvaların hemen hepsi muayyen bir alacağa (para alacağı) taallûk ederler (136). Bize en sıhhatli ölçü-

(131) Cansel, age. s. 41; bk. ayrıca Saymen - Elbir, age. s. 671

(132) Akipek, age. s. 243; kısmen Cansel, age. s. 41; Imre agm. 142-143.

(133) Esasen 907 nci maddenin aslı olan Isviçre Medenî Kanununun 939 uncu maddesinin Fransizca metninde (CCS) «retenir» kelimesi kullanılmıştır ki, bu daha çok «alıkoyma» anlamına gelir. Bu terim Türkçeye çevirme sirasında HUMK m. 13'ün tercümesinde olduğu gibi küçük bir hatayla «le droit de rétention: hapis hakkı» olarak alınmış ve asıl hapis hakkı (MK m. 864-867) ile karıştırılmaya yol açan MK m. 907/I deki hapis hakkı (hakikatte alıkoyma hakkı) kavramı Türk Hukukuna bu şekilde gi:miştir (bk. Cansel, age. s. 169; Saymen - Elbir, age. s. 671; İmre, agm. s. 141).

(134) Cansel, age. s. 169; Imre, agm. s. 143.

(135) Bu hapis hakkı nev'ileri hakkında daha geniş bilgi için bk. Cansel, age. s. $170-172,174-181$.

(136) Konusu para alacağı clan dâvalarm HUMK m. i3.II'nin kapsamına girmeyeceği hakkinda bk. 4. HD 16.10.1964, $8440 / 4900$ :Ersoy, m. 13 s. 35$)$. 
yü burada da yine gayrımenkulün aynının dâvanın vasıtasız müddeabihini teşkil edip etmemesi (137) verecektir.

Gayrımenkul mahkemesinin kesin yetkisine tabî bulunmayan dâvalardan ilk olarak gayrımenkul rehni ( $\mathrm{MK} \mathrm{m}$. $765 \mathrm{vd}$.) nev'ilerinden ipotek ( $\mathrm{MK} \mathrm{m} .796$ vd.) ve ipotekli borç senedinin ( $\mathrm{MK} \mathrm{m}$. 812 vd.) konusu ile ilgili olanları zikredebiliriz (138). Zira gerek ipotekde, gerek ipotekli borç senedinde alacak tamamen şahsî karakterdedir ve bu alacak irad senedinde olduğunun aksine gayrımenkule tamamẹ yabancıdır, gayrımenkulün dışında doğmuştur ve gayrımenkul olmadan da bunun varlığı düşünülebilir. İpotek ve ipotekli borç senedinin konusu olan alacak sebebiyle açllmış olan dâvalarda, dâvanın dolaysız müddeabihini bu alacak teşkil eder. $\mathrm{Bu}$ itibarla gayrımenkulün bünyesinden tamamen müstakil olan mahiyetinden ötürü bu alacağa ilişkin dâvaların (139), dâva konusu alacak gayrımenkul rehni ile temin edilmiş olmasına răgmen, ilgili gayrımenkulün bulunduğu yerin yargı çevresi içinde görülmeleri gerekmez; yani 13 üncü maddenin kesin yetkisinin burada

(137) Bk. dip not 47 civars.

(138) İad senedinde (MK m. $817 \mathrm{vd}$ ) ise durum lamamen başkadır (bk. dip not 100 civarı).

(139) Meselâ ipotek senedine bağlı alacak dâvası bakımından hal böyledir (bk. İID 25.12.1949, 4393/4354 «Çatalkaya - Tarkoğulları, Yeni İçtihatlı Hukuk Usûlü Muhakemeleri Kanunu, Ankara 1965, m. 13 No' 6»). Postacıoğlu aksi kanaattedir. Bu müellife göre, ipotekle temin edilmiş alacağın mevcudiyeti ve miktarı hakkındaki uyuşmazlıkların, gayrımenkule ilişkin bir hak olmaları dolayısıyla, gayrımenkulün bulunduğu mahal mahkemesinde görülmeleri gerekir (age. s. 116); keza Belgesay da ipotekle temin edilmis alacağa ilişkin dâvaların gayrımenkulün bulunduğu yer mahkemesinde görülmesi zorunluğunu kabul etmektedir (age. m. 131 a). Öte yandan İIK nun hükümleri de ipotekle temin edilmiş alacağın icrası bakımından 13 üncü maddenin kesin yetkisini kabul eder yönde değillerdir. Ipoteğin paraya çevrilmesi yoluyla takip, ister ilâmlı, ister ilâmsız olsun yetkiyi İIK $m$. 148 hükmü tayin edecektir. Bu hüküm gayrımenkul ipotek alacağı dolayısıyla takip talebinin yapılacağ 1 yetkili icra dairesinin ya İK m. 50 deki yetki hükümlerine veya gayrımenkulün bulunduğu yere göre tayin edilmesi gerektiği şeklinde alternatif karakterde bir esas koymuştur (karş. Kuru, İcra ve İlâs Hukuku c. I, İcra Hukuku, Ankara 1965, s. 400, bk. ayrıca s. 405). 
mutlaka uygulanması (140) hususunda herhangi bir mecburiyet yoktur (141).

Gayrımenkullerin kiraya verilmesi dolayısıyla çıkan uyuşmazlıklar da, tamamen o kira sözleşmesinin doğurduğu şahsî karakterdeki ihtilâflar olup (142), kiralanan gayrımenkulün aynıyla hiçbir ilişkisi bulunmamasından ötürü 13 üncü maddenin kapsamına girmeyeceklerdir.

Gayrımenkullerin kiralanmasında en sık rastlanan uyuşmazlık kiralanan gayrımenkulün tahliyesi ile ilgili olanlardır. Bu konuda görevli olacak mahkeme gerek HUMK muzda, gerek Gayrımenkul Kiraları hakkındaki kanunda (143) açıkça belirtilmiş (m. 10) olduğu halde, yetki hususuna değinilmemiştir. Bu kanunlarda mevcut olan boşluk doktrin ve içtihat tarafından doldurulmuştur. Doktrin ve içtihatın bu mevzudá ittifakla kabul etmiş oldukları görüş ise, kiralanan gayrımenkullerin tahliyesi ile ilgili uyuşmazhıların çö-

(140) Aynı hal irad senedi bakımından da yanlız bir halde mümkün olabilecektir. Gayrımenkul irad senedinin faizlerine karşllk olmaktan çıtığı tarihten itibaren o faizler malikin şahsî borcu olurlar ( $\mathrm{MK}$ m. 821/II C. 2). Yani bu durumda gayrımenkul borcun borçlusu olmaktan kurtuluyor ve şahıs borçlu duruma giriyor. Şu halde çıkacak bir uyuşmazlıkta dâvanın da artık mutlaka gayrımenkul mahkemesinde açılması (bk. dip not 100 civarı) gerekli olmayacaktır (karş. MK m. 763 C. 2 ve dip not 160 civarı).

(141) Karş. ZPO § 25. Bu maddeye göre: Ípotek, ipotekli borç sẹnedi veya irad senedinden mütevellit bir dâva ile birlikte aynı dâvalıya karşı açılan alacak dâvasıı gayrımenkul mahkemesinde açılabilir. Bern Usûl Kanununa göre: Eğer gayrımenkul rehin hakkının tanınmasına (kabulüne) dair olan bir dâva, rehin hakkı ile temin edilmiş olan bir alacağın ödenmesine veya tanınmasına (kabulüne) dair bir đâva ile birleşmiş bulunmaktaysa, o zaman bu dâva borçlunun ikametgâhı mahkemesinde de açılabilecektir (Art. 29/1 C. 2 ; bk. Leuch, age. Art. 29 No. 6, 7).

(142) Karş. Keller, Die Zivilprozessordnung für den Kanton Aargau, 3. Aufl., Aarau 1947, s. 29 No. 5; von der Crone, age. s. $45-46$.

(i43) No. 6570, 18.5.1955 (RG 27.5.1955, S. 9013). 
zümünde yetkili mahkemenin 13 ünćü maddeye göre tayin edilmesi icap etmeyeceği merkezindedir (144) (145).

Kiralanan gayrmenkullerin tahliyesinden başka, kira bedelinden doğan alacak dâvalarının da ilgili gayrımenkulün bulunduğu yer mahkemesinde görülmesi şartı aranmamaktadır (146) (147).

Ecrimisil (148) dâvaları mahiyetleri itibariyle gayrımenkulün aynı ile ilgili değildirler. Bu sebepten bu gibi dâvalar birer alacak dâvası olarak kabul edilmektedirler. O halde bu dâvaların meselâ dâvalının ikametgâhı mahkemesinde açlması mümkündür (149).

Gayrımenkuller hakkında olmakla beraber gayrımenkulün aynma ilişkin bulunmayıp, tamamen şahsî karakter taşıyan diğer bị takım münasebetlerden doğan uyuşmazlıklar sebebiyle açılacak sair dâvalar da tabiatıyle 13 üncü maddenin mutlak yetkisinin kapsamı dışında kalacaklardır. Meselâ gayrımenkule vakî tecavüz dolayısıyla tazminat itası (150), gayrımenkul satış vaadini mutazammin mukavelenin feshi (151), ferağ bedelini ketm (152), noksan verilen arsa bedelinin tahsili (153), gayrımenkul inşaat bedeli (154), tapu

(144) Bilge, MYH s. 176; Kuru, HMU s 114; HGK 30.1.1963, 6-17/5 (Ersoy, m. 13 s. 35); HGK 10.4.1946, 3-60/41 (Ömerbaș-Cetintaş, Temyiz Mahkemesi Hukuk Genel Kurulu Emsal Kararları ve İçtihatı Birlestirme Kararları 1946-1953, Ankara 1953, s. 348 -349).

(145) Buna mukabil daha eski tarihli bir Yargitay Kararı kiralanan gayrımenkullerin tahliyesi dâvalarının 13 üncü maddenin kapsamına girmesi gerektiŏi yönündedir (bk. 3. HD 1.10.1931, 10017/9007 «Atasayan, m. 13 s. 114»).

(146) Belgesay, age. m. 131 b; Bilge. MYH s. 176; Kuru, HMU s. 114; HGK 30.1.1963, 6-17/5 (Ersoy, m. 13 s. 35); 3. HD 8.10.1956, 6510i 4763 (Catalkaya - Tarıkoğulları, Içtihatı HUMK m. 13 No. 9).

(147) Alman Hukukuna göre kira akdinin feshi dâvası için kiralanan gayrımenkulün bulunduğu yer mahkemesinin kesin yetkisi kabul edilmiştir (Mieterschutzgesetz \$ 7).

(148) Bk. Türk Hukuk Lûgati, s. $79-80$.

(149) 6. HD 6.4.1962, 1825/2753 (Demirhan - Tazebay, m. 13 No. 1358); HGK 21.1.1959, 3-3/2 (IBD 1952, s. 506); 3. HD 2.11.1954, 8483/6153 (Karaok, m. 13 No. 18).

(150) 3. HD 19.6.1951, 9731/7217 (Atasayan, m. 13 s. 113); karş. Leuch, age. Art. 29 No. 1; von der Crone, age. s. 4.6.

(151) 4. HD 28.10.1950, 4870/5109 (Atasayan, m. 13 s. 114).

(152) 4. HD 12.2.1949 (Atasayan, m. 13 s. 115).

(153) 4. HD 16.7.1953, 4300/3305 (Dinçer-Kazanci, m. 13 No. 4).

(154) 4. HD 6.10.1939 (Demirhan-Tazebay, m. 13 No. 1347). 
sicilinde mukayyet ismin tashihi (155) dâvaları gibi. Bunlardan başka meselâ satılan gayrimenkulün ayıplı olmasından dolayı tazminat verilmesine (156), gayrımenkul satış mukavelelerinin ifasına, tapu siciline şerh verilmemiş olan şuf'a, iştira ve vefa haklarına ilişkin iddiaların da, bunlardaki şahsî karakterin galip vasf1 dolayısıyla, m. 13 ün kapsamı dışında kalmaları icap eder (157).

Burada MK m. 763'e de temas etmek gerekir. Bu maddenin birinci fıkrasında gayrımenkul mükellefiyetinin borçluya karşı şahsî bir alacak husule getirmiyeceği ifade edildikten.sonra, ikinci fıkrasında gayrımenkul mükellefiyeti dolayısıyla verilecek veya yapılacak şeyin, muaccel olduğu tarihten itibaren üç sene sonra (158) șahsî borç haline geleceği ve takyit edilen gayrımenkulün artık bu borcun karşılığı olmaktan çıkacağı hükme bağlanmıştır. Gayrımenkul mükellefiyetinden çıkan uyuşmazlıklar daha önce de (159) temas edildiği üzere o gayrımenkulün aynına ilişkin olmaları dolayısıyla 13 üncü maddenin kapsamına girerler. Fakat MK m. $763 \mathrm{C}$. 2 nin açık ifadesinden de anlaşılacağı gibi, başlangıçta gayrımenkul mükellefiyeti olarak tesis olunan bir edim muacceliyet tarihinden itibaren üç yılın geçmesiyle bu özelliğini kaybediyor ve gayrımenkul borcun karşılığı olmaktan çıkıyor. Bu durum karşısında, doğacak bir uyuşmazlıkta, temeli o gayrımenkul olan gayrımenkul mükellefiyeti dâvanın vasıtasız müddeabihi olmaktan çıkar ve gayrımenkul mükellefiyetine konu teşkil eden edimler artık yükümlü gayrımenkul malikinin alelâde, yani şahsî borcu haline dönüşürler (160). Bunun sonucu ise, gayrımenkul mükellefiyetinin konusundan dolayı çıkacak bir uyuşmazlıkta yetki meselesi başlanģçta 13 üncü maddeye göre tayin edilirken, muacceliyetten itibaren üç yıl geçtikten sonra yetkili mahkemenin artık mutlaka 13 üncü maddeye göre tayin edilmesinde kanunî bir zorunluluk olmaması şeklinde ortaya çıkacaktır.

Son olarak, acaba gayrimenkul mahkemesinde aynî iddialarla birlikte şahsî bazı iddialar da ileri sürülebilir mi? Bir fikre gö-

(155) 5. HD 15.5.1955, 8392/174 (Karaok, m. 13 No. 14).

(156) Bk. Keller, age. $\S 12$ d 5 .

(157) Karş. Böckli, age. § 14 No. 4.

(158) Bk. MK m. 762.

(159) Bk. dip not 92 civarı.

(160) Karş. Göktürk, age. s. 1010. 
re (161), mevzuu hem gayrımenkul, hem de bir menkul olan dâvalarda, eğer istenen şey bu gayrımenkulün teferruatı sayılabilirse dâva o gayrımenkulün bulunduğu yer mahkemesinde görülecektir. Biz bu fikre kısmen iştirak edeceğiz. Şöyle ki, eğer gayrımenkulün aynına ilişkin dâvanın yanı sıra teferruata müteallik ileri sürülen iddia tamamen talî mahiyette bulunmakta ve doğrudan doğruya o gayrımenkul dâvası dolayısıyla ortaya çıkmış bulunmaktaysa, bu takdirde teferruata ilişkin bu iddianın da gayrımenkul mahkemesinde halledilmesi uygun olur. Fakat menkul bir mal olan bu teferruata ilişkin iddia, gayrımenkulün ayın dâvasından tamamen müstakil karakterde olup, sebep ve neticeleri bakımından da gayrı menkul ayın dâvası ile hiçbir bağlantısı bulunmamakta ise, o zaman teferruata ilişkin dâvanın gayrımenkul mahkemesinde açılması için herhangi bir mecburiyet bulunmamaktadır (162).

\section{5) Gayrımenkullere ilişkin Nizasız Kaza (NK) işlerinde yet- kili mahkeme}

NK işleri başta Medenî Kanun olmak üzere çeşitli kanunlarımiza serpiştirilmiş bulunmaktadır. NK bir dâva olmadığından (163) ve dolayısıyla bir dâvalı da bulunmadığından, NK için nizalı kazada olduğu gibi bir genel yetki hükmü de (HUMK m. 9) mevcut değildir. Bu durum karşısında bu sahada prensip itibariyle - eğer varsa-mukabil alâkadar olan şahsın, yoksa bizzat talep sahibinin ikametgâhı mahkemesinin yetkili bulunması tezi savunulmuş, ancak muayyen bazı hallerde şeyin bulunduğu yer mahkemesinin yetkili olacağı (164) belirtilmiștir ki bu haller gayrımenkullere ilişkin NK işleridir.

Gayrımenkullerin fevkalâde zamanaşımı yolu ile iktisaplarına (MK m. 639) dair tescil bir NK işidir (165). Bundan başka gayrı-

(161) Belgesay, age. m. 13 No. 3, ayrica No. 1 a.

(162) Bern Usûl Kanununa göre teferruata ilişkin dâvalar gayrımenkul mahkemesinde veya dâvalının ikametgâhı mahkemesinde görülebileceklerdir (Art. 29/III). Fakat bunun için dâvanın münhasıran bu teferruata ilişkin olmaması gerekir (Leuch, age. Art. 29 No. 5).

(163) Kuru, Nizasiz Kaza, Ankara 1961, s. 15 vd.

(164) Kuru, NK s. $134-135$.

(165) Bk. Kuru, NK s. 89 vd. Bundan başka gayrımenkul malların 1515 SK'un (Tapu kayıtlarından hukukî kıymetlerini kaybetmiş olanların tasfiyesine dair kanun, 2.6 .1929 «RG. 9.6.1929 S. 1211») 1 inci 
menkuller üzerindeki intifa hakkında bu hakka konu teşkil eden kisımların resmî bir defterinin tutulmasina karar vermek (MK m. 735, HUMK m. 553-560), tapu memurunca düzenlenen ipotekli borç senetlerinin yetkili hakim tarafından imzalanması (MK m. 826/I), tapu sicilinde kayıtlı bulunan bir aynî hakkın sukût edip etmediğine dair mahkemece karar verilmesi (MK m. 934/III) halleri hep NK işlerinden olup (166), bütün bunları yapmaya yetkili olan mahkeme (hakim) ilgili gayrımenkulün bulunduğu yer mahkemesi (hakimi) olacaktır (167). Son olarak tapu sicilindeki hataların tashihine karar vermek de (MK m. 935/I, Tapu Sic. Niz. m. 107) (168) (169) mahkeme marifetiyle olur ve yetkili mahkeme ne Medenî Kanunda ne de Tapu Sicili Nizamnamesinde belirtilmemiş olmakla beraber, işlem gayrımenkulün aynına ilişkin olduğundan, genel prensibe uygun olarak gayrımenkulün bulunduğu yer mahkemesi olacaktır (170).

Buna karşıllı yine aynî haklara ilişkin NK işlerinden olan gayrımenkuil rehninde, ismi ve ikametgâhı bilinmeyen alacaklıya sulh hâkimliğince kayyım tayin edilmesinde ( $\mathrm{MK}$ m. 795) ve ipotekli borç ve irad senetleri ile faiz kuponlarının iptaline karar vermede (MK m. 839-840) (171) yetkili mahkemenin gayrımenkul mahkemesi olması gerekmez; zira bu gibi NK işlemleri gayrımenkulün aynına taallûk etmezler (172).

Hukuk Usulû Muhakemeleri Kanunumuzda da NK ya ilişkin olan bazı hükümler sevkedilmiş bulunmaktadır (173). Bunlar

maddesine göre, yapilacak tescilleri ve tapuda kayıtlı bulunmayan fakat şahısların tasarrufu altında bulunan gayrımenkullerin tapuya tescillerine karar verilmesi (1515 SK'a ek 5519 SK 25.1.1950 «RG 31.1.1950, S. 7420», m. 1) muamelesi de t1pk1 MK m. 639 gereğince yapılan işlemlerde olduğu gibi NK işlerindendir (bk. Kuru, NK s. 96).

(166) Kars. Kuru, NK s. 97.

(167) Karş. Kuru, NK s. 135.

(168) Kars. ZGB Art. 977/I; BGB § 894.

(169) Bk. Kuru, NK s. 97 vd.

(170) Karş. Schönke, age. \$ 40 III 1 a; Rosenberg, age. $\$ 35$ II 2. a; Blomeyer, age. 5 IV $3 \mathrm{~h}$.

(171) Bk. Kuru, NK s. 97.

(172) Nitekim Kurú da bu işlemleri şeyin bulunduğu yer mahkemesinin yetkisi altında zikretmemiştir (bk. NK s. 135 No. 3).

(173) Karş. Postacıŏ̆lu, age. s. 93. 
«Temhir Usûlü» ve «Tahrir» başlıkları altında 546-552. ve 553560. maddelerde hükme bağlanmışlardır. Gerek temhir ve gerek tahrir işleri gayrımenkuller hakkında olup da bunların aynına taallûk eden işler dolayısıyla yapıldıkları takdirde, yetkili mahkemenin genel kaideye uygun olarak o gayrımenkulün bulunduğu yer mahkemesi olacağı tabiîdir.

Öte yandan Kat Mülkiyeti Kanununda da NK ile ilgili hükümler mevcuttur. Bu kanunun 34 üncü maddesine göre: «Kat malikleri ana gayrımenkulün yönetiminde anlaşamaz veya toplanıp bir yönetici atayamazlarsa, o gayrımenkulün bulunduğu yerin sulh mahkemesince, ........... gayrımenkule bir yönetici atanır» (f. VI). Aynı maddenin yöneticinin muayyen müddet zarfında ancak onu atayan mahkemece değiştirilebileceğine dair olan hükmü (f. VII) NK ya ilișkin bulunduğu gibi, yönetim plânının değiștirilmesi konusunda kat maliklerinin anlașamamaları halinde hakimin müdahele edeceğini hükme bağlayan $\mathrm{m}$. 28/III hükmü de NK işlerindendir. Görüldüğü gibi kanun koyucu burada gayrımenkul mahkemesinin kesin yetkisini kabul etmiş bulunmaktadır. Halbuki genel kaideye göre, bir gayrımenkule idareci tayin etmek, o gayrımenkulün aynına ilişkin bir iş olmadığından bu konuda mutlaka gayrımenkul mahkemesinin yetkili olması gérekmiyecekti.

\section{6) Dâvanın birden çok gayrımenkule ait olması}

Dâvanın birden çok gayrımenkule ait olması halinde kanunumuz mehaz kanuna uygun olarak, bu gayrımenkullerden birinin bulunduğu yer mahkemesinin yetkili olacağını hükme bağlamıştır (HUMK m. 13/III) (174). Hükmün ifade tarzından kanunumuzun dâvacıyı bu seçimi yapmakta tamamen serbest bırakmıș olduğu anlaşılmaktadır. Şu halde dâvacı, eğer dâvası birden çok gayrımenkule ilişkin bulunmaktaysa, bunlardan herhangi birinin tabî bulunduğu mahkemede dâvasını açabilecektir. Gayrımenkullerin hepsinin aynı mahkemenin yetkisine tabî olması halinde durum güçlük arzetmeyecek ve dâvacı dâvasını o mahkemede açacaktır. Fakat hükmün sevkinden maksat, bu gayrımenkullerin başka başka mahkemelerin yargı çevreleri içinde bulunması hali içindir.

(174) CPCN Art. 11/III; karş. 1295 tarihli Usûlü Muhakematı Hukukiye Kanunu'na ek 1327 tarihli kanun m. 1. 
Kanaatimizce 13 üncü maddenin bu üçürcü fıkrası hükmünü lâfzın ifade ettiğinden daha dar bir voruma tâbi tutmalı ve dâvacı dâvasını istediği gayrimenkulün mahkemesinde açmak hususunda tamamen serbest olamamalıdır. Meselá kjymet esasına göre hareket edilip, değeri en yüksek olan gayrımenkulün bulunduğu yer mahkemesinin yetkili olduğu kabul edilebileceği (175) gibi, daha isabetli olarak uyuşmazlığın esasının veja ehemmiyetli bölümünü̈n ilişkin olduğu gayrimenkulün mahkemesinde dâva açmak yoluna da gidebilir. Bu ikinci şlk tercih edilecek olursa, aynı zamanda 13 üncü maddenin sevkedilmesindeki gayeye (176) uygun hareket edilmiş olunduktan başka, ayrıca dâvacının dâvalı aleyhine kötü niyetli bazı davranışlara başvurmasinin da önüne geçılmiş olur. Eğer uyuşmazlık muhtelif mahkemelerin yetkilerine tâbi bulunan birden ziyade gayrimenkule aynı ölçüde ilişkin bulunmakta ve maddî bakımdan birinin diğerine tercihi mümkün görülmemekte ise, bu takdirde $\mathrm{m}$. 13/III hükmüne uygun olarak dâva dâvacinın seçmiş olduğu gayrimenkul mahkemesinde açlabilmelidir.

Eğer uyuşmazlık konusu olan gayrımenkuller aynı şahsa değil de başka başka kimselere ait bulunmaktaysa,açılap dâvada bütün bu şahısların hasım gösterilmesi gerekli midir? Fikrimizce dâva hangi gayrimenkulün mahkemesinde açılmışsa, uyuşmazlı̆̆ın mahiyetine göre dâvanın sadece o gayrımenkulün maliki zilyedi, hapis (alıkoyma) hakkı sahibi vs. aleyhine açılmış olması kâfi değildir. Zira dâvanın uyuşmazlık konusu gayrımenkullerden sadece bir tànesinin mahkemesinde açılması prensibi usûl hukuk bakımından kabul edilmiş bir kolaylıktır ve hiçbir zaman dâvada gayrımenkul maliklerinin tamamının hasım gösterilmesi gerekmiyeceği anlamına gelmez..Burada dâvanın açılmasıyla gayrımenkul malikleri veya diğer ay.. nî hak sahipleri arasında HUMK m.43 anlaminda bir dâva arkadașlığı doğar. Dâvanın pasif tarafını teşkil edenler HUMK m. 44'e göre hareket ederlerse de, bunların dâvaya bakan mahkemenin yargı çevresi içinde müşterek bir ikametgáh göstermeleri (HUMK m. 44 C. 3) şartı aranmamalıdır ; çünkü bu ihtiyacı m. 13/III hükmü karşılamaktadır.

(175) Meselâ Vaud Kantonu Usûl Kanununun dâvanın kadastroya göre kıymeti en fazla olan gayrımenkulün bulunduğu mahal mahkemesinde görülmesi gerektiğini kabul ettiğini Belgesay zikretmektedir (age. m. 13 No. 4).

(176) Bk. dip not 42 civarı. 
7) Gayrimenkulün birden çok mahkemenin yargı çevresindc bulunması

a) Gayrımenkulün fi ilen bu 1 und $\mathrm{n}$ ğ $u$ y e $\mathrm{r}$

Yargitay içtihatlarına göre (17'7) gayrımenkulün bulunduğu yer tabiri ile, bu gayrımenkulün tapuda kayıtlı bulunduğu mintıkanın değil, bilâkis o gayrımenkulün fiilin kâin olduğu mahallin anlaşılması icabetmektedir. (178). Gayrımenkulün fiilen kâin olduğu yer ile tapuda kayıtlı bulunduğu mahallin aynı yargı çevresi olması halinde ise tabiatıyla böyle bir mesele bahis konusu olamiyacaktır. Tapu kaydının gayrimenkulün bulunduğu yerden başka bir mahalde görülmesi halinde fiilî duruma üstünlük tanımanın sebebi, yine 13 üncü maddenin sevkindeki gayeñın (179) normal bir tezahürun. den ibarettir.

b) Gayrimenkuliun birden fazla y a r g 1 çevresinde bul $1 \mathrm{~nm}$ as 1 halinde yet$\mathrm{k}$ i n i n tâ y i n i

Dâva konusu gayrımenkulün birden çok mahkemenin (180) yargı çevresinde bulunması halinde yetkili mahkemenin hangi esasa göre tâyin edileceğini tesbit eden bir hüküm HUMK nda yer almamıştır. Doktrin ve içtihatiar da bu probleme yabancı kalmışlardır. Halbuki meselâ Alman Usûl Kanunu bu meseleye değinmiş ve dâvanın gayrımenkulün bulunduğu yer mahkemesinde açlmasinm zorunlu olduğu hallerde, eğer o gayrımenkul muhtelif yarg1 çevrelerinde bulunmaktaysa, yetkili mahkemenin en yakın üst derece mahkemesi tarafından tâyin edileceğini hükme bağlamıştır (\$ 36/4) (181).

Kanunumuzda mevcut bu boşluğu gidermek için H.U.M.K. m. 13/III de olduğu gibi, böyle bir durumda dâvacının dâvasinı, gaay-

(177) 4. HD 25.9.1939 (Demirhan-Tazebay, c. I m. 13 No. 1346); 1. HD 4.2.1935, 388/260 (Atasayan, m. 13 s. 115-116); ayrıca bk. Akgün, agm. s. $4-5$.

(178) Karş. Rosenberg, age. $\$ 53$ III 4.

(179) Bk. dip not 42 civar1.

(180) Buradaki mahkeme sözüyle Türk Yargısına tabî bulunan yargı mercileri kastedilmektedir (karş. Wieczorek, age. \$36 D IV; Ro-

(181) Karş. Stein-Jonas, age. \$ 36 III 4; Wieczorek, age. \$36 D IV; Rosenberg, age. \$ 35 III 4. 
rımenkulün yarğı çevresi içinde bulunduğu mıntıkalardan dilediğinin mahkemesinde açabileceğini kabul edebiliriz. Ancak daha önce de (182) belirtildiği gibi, insiyetifi tamamen dâvacının eline b1rakmak dâvanıri seyrini 13 üncü maddenin sevkedilmesindeki maksattan uzaklaştırabilir ve dâvacinın muhtemel bazı kötü niyetli davranışlarına yol açabilir. Bu itibarla burada da adı geçen bölümde söz konusu etmiş olduğumuz kiymet esasına (183) paralel olarak, gayrımenkulün saha itibariyle büyük kısmının bulunduğu yer mahkemesinin yetkili olması gerektiği bir çözüm yolu olarak akla gelebilir (184). Fakat fikrimizce burada da en münasip ve 13 üncü maddenin gayesine uygun çözüm yolu, dâvanın birden çok gayrimenkule ait olması halinde olduğu gibi, uyuşmazlığın esasının veya ehemmiyetli bölümünün ilgili olduğu mintıka mahkemesinin yetkisini kabul etmek olacaktır (185).

c) G a y r 1 menkulü n hang i y a r g 1 çe v r esinde bulunduğ nun kesin ol a rak b i l i n e me mes i

$\mathrm{Bu}$ konuda bir tereddüdün bulunması halinde, bunu gidermek için durumu sadece idarî makamlara (İçişleri Bakanlığı, valilik, kaymakamlık) sormak ve yetkiyi bu mercilerin verecekleri cevaplara göre tâyin etmek kâfi gelmez (186). Uyuşmazlık konusu gayrımenkulün hangi yargı çevresinin hudutları içinde kaldığının tam olarak tesbiti için, ayrıca mahallinde keşif yapılması ve durumun buna göre tâyini icabeder (187). Bundan dabir sonuç alınamaması ha linde yetkili yargı çevresinin belirtilmesi HUMK m. 25 hükmüne uy-

(182) Bk: dip not 176 ve $4 z$ civarı.

(183) Bk. dip not 175 civar1.

(184) Karş. Akgün, agm. s. 4. Bu müellife göre, meselâ müddeabih mer'anın $1 / 3$ ü bir ilçe, $2 / 3 \ddot{u}$ diğer bir ilçe hudutları içinde ise, cüz külle tabî olacak ve yetkili mahkeme arazinin $2 / 3$ ünün bulunduğu ilçe mahkemesi olacaktır. Müellif devamla 1944 yılında Alaca hakimi bulunduğu sırada böyle bir karar verdiğini ve bu kararın Yargitayca da onandığını zikrediyor (agm. s. 4); keza von der Crone, age. s. 62 .

(185) Aksi fikirde Wieczorek, age. $\S 36$ D IV a.

(186) Aynı fikirde Kuru, HMU s. 115; aksi görüşte: 5. HD 9.10.1950. $3533 / 1221$ ve $29.12 .1950,4933 / 4355$ (Karaok, m. 13 No. 7). 
gun olarak üst derece mahkemesince (Yargitay 4. HD) mercî tâyini yoluyla sağlanmalidır (137 a).

8) Adlî teşkilâtta yapılan değişiklik sebebiyle gayrımenkulün yeni bir mahkemenin yetkisine tâbi olması

Ana kaide yetkili mahkemenin dâvanın açılmıș olduğgu andaki duruma göre tâyin olunacağı merkezindedir (188). Bu tarihten sonraki değişiklikler artık mahkemenin yetkisine tesir edemiyeceklerdir. Meselâ dâvalının dâva tarihindeki ikametgâhı A ilçesindeyken, dâvalının ikametgâhını daha sonra B ilçesi sınırları içine nakletmiş olması, açılmış olan bu dâva bakımından A ilçesi mahkemesinin yetkisini etkilemiyecek ve dâvanın görülmesine bu mahkemede devam edilecektir. Fakat eğer dâva esasen yetkisiz olan bir mahkemede açılmış bulunmaktaysa, dâvalı bu hususu HUMK m. 187/II No. 2 gereğince ilk itiraz olarak ileri sürmelidir. Bilindiği gibi ilk itirazlar dâvanın başında esasa girișilmezden önce hep birlikte ileri sürülmezlerse sonradan dinlenemezler (189) Mahkemenin yetkisine itiraz eden taraf yetkili mahkemeyi beyan etmeli (HUMK m. 23 C. 4) ve eğer dâvalının bu itirazı kabul edilirse mahkeme dâva dilekçesinin ve dosyasının ait olduğu mahkemeye gönderilmesine karar vermelidir (HUMK m. 27). Mahkemenin yetkisizliğe dair vermiş olduğu bu karar kesinleşirse, dâvacının kesinleşme tarihinden itibaren 10 gün içinde yetkili mahkeme kanalıyla dâvalıya tebligat yaptırmaș gerekir (HUMK m. 193/II, III). Mahkeme yetkisizliğine karar verirken, dâvacıyı muhakeme masraflariyla vekâlet ücretine de mahkûm eder (190).

(187) Kars. Kuru, HMU s. 115; 1. HD 21.12.1951, 9932/5589; 7. HD 23.10.1952, 2643/3970 (Karaok m. 13 No. 9, 10).

(187a) Bütün bunlar zaman ve emek sarfına yol açtığından ve dâvaları sürüncemede biraktığından bazı müelliflerce (Ansay, age. s. 105; Bilge, MYH s. 192) bu gibi durumarda yetkili mahkemenin önceden kanunî bir hükümle belirtilmiş olması tezi savunulmaktadır. Yetkili yargı yerinin daha dâva açılmadan önce belirtilmesi içir bir müracaat imkânı tanınması fikri (Kuru, HMU s. 140) ise bize daha uygun gözükmektedir. Gayrımenkul ayın ihtilaflarında yapılan mercî tayini kesindir, sözleşme ile bertaraf edilemez.

(188) Karş. HUMK m. 9/I; Ansay, age. s. 90; Postacıoğlu, age. s. 114; Bilge, MYH s. 166; Kuru, HMU s. 137.

(189) HUMK m. 188; İBK 29.3.1944, 36/10.

(190) İBK 25.4.1945 No. 9. Kuru, bu İBK nın isabetsiz olduğu fikrindedir (bk. HMU s. 137). 
Yetkinin kamu düzeni düşüncesiyle tâyin edilmiş olduğu hallerde ise durum başka türlüdür (191). Bu sebepten dolayı gayr:menkulün aynına ilişkin dâvalar (HUMK m. 13) yönünden de mesele yukarıdaki esaslàrdan tamamen farklı bir veçhe arzetmektedir. Yargitay, gayrımenkullerin aynına ilişkin dâvalara yetkili mahkemede (mes. A ilçesi mahkemesi) bakılmaktayken, adlî teşkilâtta yapılan bir değişiklik sonucu, o gayrımenkulün bulunduğu yerde (B nahiyesi) mahkeme teşkilâtı kurulur veya gayrımenkulün bulunduğu mahal ( $\mathrm{X}$ kazasına bağlı $\mathrm{Z}$ köyü) başka bir yargı çevresine ( $\mathrm{Y}$ kazasına) bağlanırsa, görülmekte o-. lan bu gibi dâvalarm yeni mahkemeye devredilmesi gerektiği görüșündedir (192). Burada kamu düzeniyle ilgili bir durum karşi-

(191) Bk. Bilge, MYH s. 146.

(192) Tatbikatta bu gibi hadiselere rastlanmaktadır: «Gayrımenkulün aynına taallûk eden dâvanın rüyeti sırasında Beykoz'da asliyt mahkemesi kurulmuş olmasına binaen..... Üsküdar Asliye Mahkemesinin yetkisizlik kararı doğrudur» (4. HD 28.5.1953, 2330/2470 «Ersoy, m. 13 s. 36»); «Dâvacının dayandığı tapuda yazılı Yancıklar Köyü'nün adlî kaza bakımından Kırklareli'nden ayrılarak $P_{1}$ narhisar'da teşkil edilen mahkemeye bağlandığı...., keşifte....., bilirkişi de dâvacının tarlasının Yancıklar Köyü hududu dahilinde bulunduğunu beyan eylemesine göre..... dosyanin o mahal mahkemesine gönderilmesi gerekli iken bunun zuhul edilmesi yolsuzdur» (5. HD 4.12.1953, 7823/5806 «Dinçer - Kazanc1, m. 13 No. $3 »)$; «Nizalı gayrımenkul dâva açılmasından sonra Germencik'te teşkil olunan mahkemenin kaza çevresine girmiş bulunmasına ve HUMK m. 13 gereğince gayrımenkule müteallik dâvalara bakıılması gayrımenkulün bulunduğu yer mahkemesine ait ve racî olmasına binaẹn âmme intizamı esasina dayanan işbu 13 üncü madde hükmünün re'sen mahkemece nazara alınması.....» (5. HD 14.1.1950, 2901/18 «Dinçer-Kazancı, m. 13 No. 11»); «Dâva gayrimenkulün aynına taallûk etmesine ve dâvadan sonra Sarıyer'de asliye mahkemesi teşkil edilmiş bulunmasına ve dâva konusu gayrımenkulün Sarıyer'de kâin bulunduğunun anlaşılmasina...... ......binaen Sarıyer Asliye Mahkemesinin..... mercî tayinine ......» (4. HD 21.5.1953, 3061/2386 "Dinçer-Kazanc1, m. 13 No. 6»); ayrıca bk. HGK 24.11.1965, $6-685 / 428$ ve 1. HD 19.2.1960, 819/1197 (Demirhan-Tazebay, m. 13 No. 1357); HGK 22.9.1954, 1-78/88 (Ömerbaş-Çetintaş, Emsal Kararları 1953-1955, s. $251-252$ ); 7. HD 26.1.1954, 7466/538 ve 17.10.1953, 294/5254 (Ersoy, m. 13 s. $35-36$ ) ; 2. HD 5.5.1953, 1613/2243 (Dinçer-Kazancı, m. 13 No. 7); 1. HD 26.3.1932, 624 (Atasayan, m. 13 s. 115); bk. ayrica Adalet Bakanlığı Hukuk Issleri Umum Müdürlüğü tamim ve mütalâaları : 12.11.1953-18277, 10.8.1953-10) MT/9う33, 27.4.1953- 75 MT/953 (Dinçer-Kazanc1, m. 13 No. 11). 
smda bulunduğumuz için, dâvanın sörülmekte olduğu mıahkeme HUMK m. 187/II No. 2 deki prensip hilâfına re'sen, yâni tarafla. rın bir yetki itirazında bulunmalarını beklemeden dâvayı görmeme kararı verecek (193) ve lâva dilekçesiyle dosyasını gayrımenkulün yetkisine tâbi bulunduğu yeni mahkemeye tevdi edecektir. Ayrıca dâvanın açılmış olduğu ilk mahkeme dâvayı görmemesi gerektiğini sadece belli bir süre zarfında değil, dâvanın her halinde hattâ hükmün Yargitayca bozulmasından sonra (194) bile dikkat nazarına alabilecektir (195). Ilk derece mahkemesinin bozma kararı karşısında vermiş olduğu kararın uyma veya direnme şeklinde tecellî etmiş olmasının burada hiçbir önemi yoktur (195).

Böyle bir halin vukuunda dâvayı görmekte olan mahkemenin görmeme kararı alacağını ifade etmemizdeki, yâni «yetkisizlik » terimi yerine «görmeme» kavramını tercih etmemizdeki sebep, dâvaya bakan mahkemenin verdiği kararın teknik anlamda bir yetkisizlik kararı olmamasındadır. Zira yetkisiz mahkeme hiç yetkili ol. mamış olan mahkemedir. Buradaki mahkeme ise aslincia yetkilidir (yetkiliydi), sadece yetkisi İdarenin bir işlemi sonucu olarak son bulmaktadır; bu da bir kanun hükmüne değil, Yargitay'ın içtihatlarına göre olmaktadır. O halde eğer idarenin bu işlemi o?-

(193) Bk. HGK 24.11.1965. 6-685/428; 7. HD 26.1.1954, 7466/538 ve 17.10. 1953, 294/5254; 1. HD 26.3.1932, 624 (dip) not 192).

(194) Bunun tamamen ziddi olarak, hükmün Yargitayca bozulmasindan sonra yargilamanın mutlaka gayrımenkul mahkemesinde yapılmasi gerektiği şeklinde bir esas HUMK m. 429/I dolayısıyla, adlî teşkilâtta yapılan değişiklikle ilgili bulunmamasına rağmen, burada söz konusu edilebilir. Bilindiği üzere, HUMK m. 429/I hükmün Yargitayca bozulmasından sonra, dâva dosyasının bu hükmü veren mahkemeden başka bir mahkemeye de gönderilebileceğini ifade etmektedir. Fakat eğer bozulan hüküm, bir gayrinenkul ayırı dâvası dolayısıyla verilmiş bulunmaktaysa, bu takdirde dâvanın hükmü veren ilk mahkemeden (gayrımenkul mahkemesi) başka bir mahkemeye havale edilmesine kamu düzeni düsüncesiyle imkân bulunmamalıdır. Aynı durum karar tashihinden sonra da bahis konusu olabilir. Zira bu halde de bozma dolayısıla Yargitay dosyayı asıl mahkemeden başka bir mahkemeye gönderebilmektedir (bk. Bilge, MYH s. 596); fakat kamu düzeni fikri burada da gayrımenkul ayıın dâvaları bakımından bu imkânı bertaraf eden bir tanzim şeklinin kabul edilmesini zorunlu kılacaktır.

(195) Karş. HGK 22.9.1954, 1-78/88 (Ömerbaş-Çetintaş, Emsal Kararları $1953-1955$, s. $251-252$ ). 
masayd 1 o mahkemenin yetkis: yine devam edecekti. Bu itibarla dosyanın burada dâvayı görmekte olan mahkemeden yeni kurulmuş olan mahkemeye gönderilmesi hususunda verilmiş olan karar yetkisizlik kararı değil, bilâkis bir «devir kararı» dır (196). Bu bakımdan gayrımenkule ilişkin ayın dâvalarında dâva evrakının yeni mahkemeye devir ve tevdii hakkında HUMK m. 193/III deki 10 günlük müddet uygulanamayacaktır (197). Bundan başka devir kararı sebebiyle dâvacı vekâlet ücreti ile sorumlu tutulamıyacağı (198) gibi muhakeme glyajbında cereyan eden tarafa yeniden tebligat yapılması da icap etmeyecektir (199). Dâvayı devralan mahkeme, bu dâvaya baştan değil, ilk mahkemenin bıraktığı yerden devam edecek (200), gayrımenkulün tâbi kılındığ1 yeni mahkemede tekrardar harç ödemek de gerekmeyecektir (201).

Şu halde adlî teşkilâtta yapılan bir değişiklik dolayısıyla gayrımenkulün bulunduğu yerde yeni bir mahkeme kurulur veya o gayrımenkulün bulunduğu mıntıka başka bir yargı çevresine bağlanırsa, bu gayrımenkulün aynına ilişkin dâva dosyasının dâvanın görülmekte olduğu mahkemeden yeni kurulan mahkemeye devir ve tevdii gerekir (202) (203). Bu devir işi dâvanın her halinde, hattà hükmün Yargitayca bozulmasindan sonra bile mümkündür. Fakat acaba verilen hüküm aleyhine yargilanmanin iadesi yoluna gidilmişse durum ne olacaktır? Yani yargilamanın iadesi dâvası gayrımenkulün tâbi bulunduğu yeni mahkemede mi açlacak, yoksa ilk hükmü veren mahkeme mi yetkili olacaktır? Bu konuda dok-

(196) Bk. IBK 18.6.1958, 21/10 (RG 1.10.1958, S. 10021); Kuru, HMU, s. 138.

(197) IBK 18.6.1958, 21/10; 7. HD 10.6.1957, 3408/7444 (Ersoy, m. 13 s. 35$)$.

(198) HGK 11.5.1955, 5-38/35 (Ömerbaş-Çetintaș, Emsal Kararları 1953 1955, s. 253); Kuru, HMU s. 138.

(199) Bk. Karaok, m. 13 No. 16.

(200) İK 18.6.1958, 21/10; Kuru, HMU s. 138.

(201) Ad. Bak. Huk. İş. Gen. Md. 27.4.1953 tarih ve 75 MT/953 sayılı mütalâası (Öztek-Kazancı, m. 13 No. 241).

(202) 18.6.1958 tarih ve $21 / 10$ sayılı İçtihatı Birleştirme Kararına göre «Böyle bir devir ve tevdî mecburiyeti sadece yeni mahkeme teşkil edilmesi halinde değil, meselâ gayrımenkulün 2613 sayılı kanun uyarinca kadastroya, 5602 sayll kanun uyarinca tapulamaya tabî tutulması halinde veya Usûlün 25 inci maddesinde belirtildiği üzere salâhiyetli mahkemenin dâvaya bakmasına İiìlî veya hu- 
trinle tatbikat arasında tam bir uyuşma yoktur. Doktrine göre, burada m. 13 hükmünün uygulanmaması ve dâva konusu gayrımenkul sonradan başka bir mahkemenin yargi çevresine tâbi kılınmış olsa bile, yargılamanın iadesi dâvasının hükmü vermiş olan mahkemede açılması gerelkir; zira dâva ile ilgili dosya o mahkemede bulunmaktadır (204). Tatbikatta ise bu fikri teyit ve nakzeden iki ayrı karara rastlanmaktadır. Birinci karar (doktrini teyit eden) (205), HUMK m. 448/I'e dayanmakta ve yargılamanın iadesi isteğini hâvi dilekçenin, hükmü veren mahkemeye verilmesi ve orada incelenmesi esasmdan hareket etmektedir. Diğer kararda (doktrine zit) (206) ise, yargilamanın iadesinin esas itibariyle hükmü veren mahkemeden talep olunacağını, ancak gayrımenkule (gayrımenkulün aynına) ilişkin dâvaİara o gayrımenkulün bulunduğu yer mahkemesinde bakılması kamu diizeninden olduğundan, gayrımenku?ün tâbi bulunduğu yeni mahkemenin evvelki dâvayı gören mahkemenin yerine geçmesinden ötürü, yargllamanm iadesi talebinin de bu yeni kurulan mahkemede incelenmesi icabedeceği fikri savnulmaktadır. Bize bu ikinci kararda temsil edilen görïş̧ daha uygun gözükmektedir. Zira yargilamanın iadesi prosedürü tamamen normal bir dâva prosedürü gibi cereyan eder. Bu kanun yolu, dosya üzerinde inceleme yapmak suretiyle hüküm vermeye müsaade etmez (207). İade talebi üzerine yeni bir yargılama yapılacak (HUMK m. 450) ve karşı taraf kabul ettiği takdirde yeni iddia ve vakıalar ileri sürülebilecek,

kukî bir engel çıkması ve bu sebeple başka bir mahkemenin mercî tayin edilmesi takdirinde de tahaddiis edebilir» (Bilge, Hukuk Muhakemeleri Usûlü Kanunu, Ankara 1961, m. 13 No. 9) (bk. dị not 216 - 221 civarı). Tapulama işleri bakımından 766 sayılı Tapulama Kanunu ile bu devir ve tevdî işi kabul edilmemektedir (bk m. 49/II) (karş. dip not 203).

(203) Bunun bir istisnası Tapulama Kanununda (m. 49/I) yer almıştır. Bu hükme göre; «Idarî kuruluşta değisiklik yüzünden, sonradan başka bir bölgeye bağlanan birliklere ait uyuşmazlıkları çözmeye o birliğin tapulamaya başlandığı tarihte bağlı bulunduğu bölgenin tapulama hakimi yetkilidir» (karș. 7. HD 5.10.1964, 6638/5753» «Çatalkaya - Tarkoğulları, İçtihatlı HUMK, m. 13, No. 10»).

(204) Bilge, MYH, s. 627; Kuru, HMU s. 463.

(205) 1. HD 14.12.1951, 7978/5492 (Karaok, m. 13 No. 8).

(206) HGK 21.9.1955, 7-64/63 (Ömerbaş-Çetintaş, c. III s. 369-370).

(207) Kars. Kuru, HMU s. 464; 3. HD 9.1.1949, 2237/44 (Karaok, m. 450 No. 2). 
dolayısıyla yeni deliller de getirılebilecektir (208). Bütün bu yeni işlemler 13 üncü maddenin sevkindeki gayeye (209) en uygun şekilde ancak gayrımenkulün tâbi kılındığı yeni mahkemece gerçekleştirebilirler. Zira yeni kurulan bu mahkeme hükmü veren ilk mahkemeye nazaran tamamen başka, onunla hiçbir ilişkisi bulunmayan bir yargı mercii değil, aksine belli konularda eski mahkemenin yetkisine halef olan ve adetâ onun kısmen devamı bulunan bir kazaî organ mahiyetindedir. Burada yeni mahkeme eskisinin yanısıra ve onunla birlikte yetkili olmamakta bilâkis muayyen nisbette eski mahkemenin yetkisini bertaraf ederek onun yerine geçmektedir. Hal böyle iken, HUMK m. 448/I hükmünü gayrımenkul ayın dâvalarındà yargılamanın iadesi taleplerini yetkili yeni mahkemenin değil de, yetkisi son bulmuş olan eski mahkemenin inceleyeceği şeklinde yorumlamak tamamen hatalı olur. Bu itibarla yargllamanin iadesi talebini yeni gayrımenkul mahkemesinin tetkik ederek karara bağlaması (210) uygun ve mutlak surette faydalı olacaktır. Bu hal HUMK m. 448/I'e m. 13 dolayısıyla tanınmış olan bir istisna teşkil edecektir.

Fakat bütün bu söylenenler gayrımenkulün aynına ilişkin dâvalar, yâni kesin yetki halleri içindir. Dâva gayrımenkulün aynına ilişkin değilse, bu takdirde kamu düzeni düşüncesi bulunmadığından dolayı dâvanın yeni gayrımenkul mahkemesine devredilmesi gerekmez (211).

Acaba verilmiş olan bir hükmün tavzihi dolayısıyla hangi mahkemeye başvurulacaktır ? Yargitay adlî teşkilâtta yaplan değişiklik ile, hakkında hüküm verilen bir gayrımenkulün sonradan başka bir mahkemenin vetkisine tâbi kılınması halinde, gayrımen. kule dair verilmiş olan bu hükmü tavzih etmeye yeni mahkemenin yetkili olduğuna karar vermiştir (212). Yargitay bu kararında

(208) Bk. Bilge, MYH s. 628-630; İBK 23.5.1956, 8/9 ve HGK 14.9.1955, 6-54/53 (Karaok, m. 450 No. 413).

(209) Bk. dip not 42 civari.

(210) Hükmü veren mahkemeye verilen yargllamanın iadesi talebini havî dilekçenin (HUMK m. 448/I) dosya ile birlikte bu mahkemece doğrudan doğruya yeni kurulan gayrımenkul mahkemesine gönderilebilmesi -kamu düzeni düşüncesiyle- gerekir.

(211) Karş. Kuru, HMU s. 138; HGK 24.11.1965, 6-685/428; bi. ayrıca 4 . HD 13.2.1953, 801/612 ve 1036/737 (Karaok, m. 13 No. 11).

(212) Bk. 1. HD 19.2.1960, 819/1197 (Kuru, HMU s. 468/8). 
13. madde hükmünün kamu düzeninden olduğu esasından hareket etmiş olduğu için, hükmün tavzihine yetkili olacak mahkemenin, o hükmü veren mahkemeden bir başkası (yeni mahkeme) olacağını kabul etmiştir (213). Fakat Yargitay'ın bu kararı hem Usûlün $456 \mathrm{ncl}$ maddesinin hem de tavzih müessesesinin gayesine aykırı görülerek tenkit edilmiştir (213). Gerçekten Yargitayın bu görüşünde isabet yoktur. Hükmün manâsını açiklamak veya hükümde mevcut çelişkiliği gidermekten ibaret olan tavzih işlemi (HUMK m. 458/I) başlıbaşına bir dâva karakterini haiz değilaiir. 'Tavzih incelemesi kaideten dosya üzerinde yapllır; tarafların dâveti ise ancak istisnaen ve tamamlayıc bilgi verme gayesiyle (HUMK m. 457) olabilir; yoksa hakikî anlamda duruşma yapmak gibi bir durum söz konusu olmaz. Bütün bunların hükmü vermiş olan eski gayrımenkul mahkemesinde yapllmasinda 13 üncü maddenin sevk gayesine ve bu madde ile sağlanmak istenen kamu düzeni esasına aykırı bir cihet yoktur.

Bu bölümü bitirmeden evvel şöyle bir sonuca varılabilir: Eğer yeikiyi tesis eden unsurlardaki değişiklik tarafların iradesiyle olmuşsa (meselâ ikametgâh nakli), yetkili mahkeme değişmez; fakat bu değişiklik eğer kamu otaritesinin bir tasarrufu sonucu ise (meselâ gayrımenkulün bulunduğu mintıka da yeni bir mahkeme kurulmas1) yetkili mahkemenin değişen yeni şartlara göre belirtilmesi lâzımdır (214). Fakat burada yalnız kamu otoritesinin bir tasarrufunun mevcudiyeti kâfi gelmiyecek, ayrıca kamu düzeni düşüncesinin de (meselâ dâvanın gayrımenkulün aynına ilişkin olması) varlığı aranacaktır. Nitekim gayrımenkule ilişkin olan, fakat onun aynına taallûk etmeyen gayrımenkul dâvalarında bu kamu düzeni düşüncesinin bulunmayışı sebebiyledir ki, görülmekte olan gayrımenkulle ilgili dâvanın gayrımenkulün tâbi kılındığı yeni mahkemeye devredilmesi gerekeli addedilmemektedir (215).

De lege ferenda gayrımenkulün bulunduğu yerde mahkeme kurulması veya gayrımenkulün bulunduğu mahallin başka bir mahkemenin yargı çevresine bağlanması dolayısıyla gayrımenkullerin ayınlarına ilişkin dâvaların görülmekte oldukları mah.

(213) Karş. Kuru, HMU s. 468.

(214) Bilge, MYH s. 166.

(215) Bk. dip not 211 ve civarı. 
kemelerden bu yeni kurulan mahkemelere devredilmesini önleyecek hükümler sevkedilerek mevcut hükümlerin ve tatbikatın buna göre yeni baştan tanzim edilmesi düşünülebilir. Zira itiraf etmek gerekir ki, icabında gayrımenkullerle ilgili yüzlerce dâva dosyası. nin görülmekte olduğu mahkemelerden bir diğerine adlî teşkilâtta yapılan değişiklik neticesinde gönderilmesi ve dâvalara bu ikinci mahkemede devam olunması, zaman, emek ve masraf kaybina sebep olduktan başka, bazı karışılıklar da doğurabilecek niteliktedir ve pratik bir çözüm yolu olmaktan epeyce uzak bulunmaktadrr.

b) Dosyanın görülmekte olduğu mahkemeden başka bir mahkemeye devir ve tevdi edilmesi mecburiyetine sadece adlî. teşkilâtta vuku bulan bir değişiklik sonucunda yeni mahkeme kurulması halinde değil, bunun dışında bazı hanunların öngörmüş oldukları hallerde de tesadüf edilmektedir (216). Ezcümle gayrımenkulün 2613 SK. uyarınca kadastroya tâbi tutulmasında bu durum görülmekteydi. Zira adı geçen kanunun 27 nci maddesine göre, genel mahkemelerce görülmekte olan veya yüksek selâhiyet]i mahkemelerden bozularak iade kılınan kadastro ve tahrire ilişkin dâva evrakı re'sen kadastro mahkemesine devrolunurdu (f. 1). Kadastro mahkemelerinin verdikleri hükmün üst derece mahkemesince bozularak iadesi zamanında kacastro komisyonları $\mathrm{c}$ yer mahkemesinin kaza hududu dışına çımıs iseler, bu dâvaya o yerin selâhiyetli mahkemesi bakardı. (f. 3). Bugün artık bu hükmün pratik bir ehemmiyeti kalmamıştır. Zira 5572 sayılı kanunun 2 nci maddesi ile 2613 sayll kanunun 12 nci maddesi hükümleriyle kurulmuş olan Kadastro Mahkemeleri kaldırılmış ve bu mahkemeler tarafından gölülen işler o mahaldeki Adliye Mahkemelerine (Asliye Hukuk) devredilmiştir.

Keza Tapulama Kanunu da mahallî mahkemelerde görülmekte olan dâvaların tapulama mahkemelerine ve bu mahkemelerde görülen dâvaların da o yer mahallî mahkemesine devri hakkında hü-kümler ihtiva etmektedir. Bu kanunun 50 nci maddesine (217) göre «Mahallî hukuk mahkemelerinde görülmekte olan tapulama ile ilgiili bulunan ve kesinleşmemiş olan gayrımenkul dâvaları hakkında o gayrımenkul için tapulama tutanağı (217 a) tanzim edildiği tarihte

(216) Bk. İBK 18.6.1958, 21/10 (Bilge, HMUK, m. 13 No. 9).

(217) Karş. 5602 sayılı eski Tapulama Kanunu, m. 35.

(217a) Tapulama Kanunu, m. 23 vd. 
bu mahkemenin görevi (218) sona erer ve cầvalara ait dosyalar Tapulama Mahkemesine re'sen devrolunur.» 51 inci maddede (219) ise «Tapulama işlerinin bir bölgede tamamlanarak tapu kütük ve dayanağı belgelerin mahallî tapu idaresine devrinden altı ay donraya kadar tapulama mahkemesinde hükme bağlanmamış dâvalara ait dosyalar o yer Asliye Mahkemesine devrolunur» denilmektedir (C 1).

Tapulama Kanununun bu iki hükmünden de görüleceği üzere, tapulama ișleri için prensip olarak tapulama mahkemeleri gorevli ve yetkili kılınmıș olmakla beraber, bu mahkemelerin, görev ve yetkileri dahilinde bulunan işleri muayyen bazı şartlar ve müddetlere bağh olarak mohallî adalet mahkemelerince devredebilecekleri veya onlardan devir alabilecekleri de kabul edilmiştir.

Son olarak HUMK m. 25’e göre salâhiyetli mahkemenin dávaya bakmasına fiilî veya hukukî bir engel çlkması ve bu sebeple başka bir mahkemenin mercî tâyin edilmesi halinde de dâva dosyasının görülmekte olduğu mahkemeden başka bir yer mahkemesine devredilmesi kabul edilmektedir (220). Yargitay'in bir içtihadı birleştirme kararıyla tesbit edilen bu görüşün gayrımenkul ayın dâvalarmın belirtici vasfı ve hakim unsuru olan kesin yetki ve kamu düzeni esaslarıyla bağdaştırılması müșiül ise at, bir imkânsızlı̆̆ı bertaraf etme gayesine matuf en sihhatli ve mantıkî bir hal çaresi olması bakımından kabul edilmesi yerinde olur. (221).

(218) Buradaki görev kelimesini -işin mahiyeti icabı- yetkiyi de ifade eder anlamda yorumlamalıdir.

(219) Karș. 5602 SK m. 36.

(220) İBK 18.6.1958, 21/10.

(221) Ulùiün 25 inei maddesine göre, selbî veya icabî tavini mercíden sonra gayrımenkulün bulunduğu yerde bir mahkeme açlırsa, mercî tavin edilen mahkeme dâvayı yetkisizlik kararıyla bu yeni mahkemeye gönderebilir. Yalnız Usûlün 429 uncu ve 25 inci mad. delerine göre, hukukî ve fiilî imkânsızlıktan dolayı mercî tayin edilen mahkeme imkânsılığın bertaraf edilmesinden bahisle yetkisizlik kararı veremez (1. HD 28.5.1954, 987/4790 «Karaok, m. 13 No. 20»). 


\section{IV - GAYRIMENKUL (GAYRIMENKUL AYIN) DÂVALARIY- LA İLGILİ DİĞER MESELELER}

\section{1) Gayrımenkullere ilişkin hükümlerin icrası}

Kaideten temyiz icrayı tehir etmez (HUMK m. 443 C. 1). Fakat gayrımenkuller bakımından kanun bu hükme bir istisna kabul etmiştir. Buna ي̈ore «Gayrmenkule ve gayrımenkule ilişkin aynî haklara dair hükümler kesinleşmedikçe icra olunamıacaklardır» (HUMK m. 443/IV). Çünkü bu hükümlerin icrası ilgili sicillerde değişiklik yapılmasını gerektirecektır (222). Bunun için" dir ki, böyle bir işleme girişmeden evvel hükmün kat'i halini almasını beklemek kanun koyucu tarafından uygun görülmüştür. 443 üncü maddenin dördüncü fikrası hükmünün münhasıran gayrımenkulün aynına ve buna ilişkin aynî hakklara taallûk ettiği ko. nusunda bugün tereddüt mevcut değildir (223) (224). Buna karșılık kiralanmıs gayrımenkullerin tahliyesi gibi gayrımenkulün aynı veya onun üzerindeki aynî haklarla ilișkisi bulunmayan ilâmlara dair hükümlerin icra edilebilmeleri için bunların kesinleşme-. lerini beklemeye lüzum yoktur (225). Şu hususu da belirtmek ge. rekir ki, gayrımenkule ilişkin ilâmlar Yarğıtayca onansa bile, tas.

(222) Bilge, MYH s. 596.

(223) İ́D 28.9.1955, $4422 / 4958$ ve 5.7.1951, 3615/3646; 1. HD 21.11.1951. $9430 / \ldots .$. ve $9431 / \ldots \ldots ; 4$. HD $4.6 .1942, \ldots . . / 2093$; IID 18.12.1939, $4437 / 5601$ (Karaok, m. 443 No. 23, 19, 14, 7, 6); İD 19.2.1963, 2099/7159 - 14.11.1947, 3997 ve 28.3 .1940 (Kuru, İH s. $364 / 4,3$ a).

(223) Gayrımenkullerin aynına veya bunlar üzerindeki aynî haklara ilişkin uyuşmazlıklar dolayısıyla açılmış olan dâvalar sonucunda hükmedilmiş olan muhakeme masrafları ve vekâlet ücreti hakkında, fer'in asla tabî olması kaidesine binaen bu konudaki esas hüküm kesinleşmedikçe takibat yapılamaz (İID 28.9.1955, 4422/4958; IIID $13.11 .1952,3217 / 4698 ; 4$. HD 4.6.1942, .../2093 «Karaok, m. 443 No. 23, 16, 7»). Gayrımenkullere ilişkin dâvalarda alınacak harç nispetleri Harçlar Kanununda (492 SK 2.7.1964 «RG 17.7.1964, S. $11756 \gg$ ) tespit edilmiştir: Bk. m. 16, 17, 18, 24, 42 ve (1) sayılı Tarife A III 1 b-c, 2 a-b; B 3 e, 4; (2) sayll Tarife: I 3. Ayrica tapu ve kadastro işlemleriyle ilgili harçlar için bk. m. 58/e, 59, 62, 64 III, 65 ve (4) sayıl Tarifenin ilgili bölümleri; bk. ayrıca Tapulama Kanunu m. 70, 72.

(225) İBK 20.6.1938, 15/7 (Çatalkaya-Tarıkoğulları, İçtihatı HUMK, m. 443 No. 1); İK 23.2.1938, 7/11 (Bilge, HMUK m. 443/84); ItD 12.6.1945, 1668/1594 (Karaok, m. 443 No. 5, 8); İID 12.9.1958, $4556 / 4277$ ve $30.11 .1954,5108 / 5236$ (Kuru, İH s. $364 / 5$ ). 
hihi karar süresi geçmedikçe bunların icrası caiz olmayacaktir (226).

Genel kaide ilâmlarm icrasının her icra dairesinden istenebileceği (İK m. 34) şeklindedir. Yargıtay bu prensibi mutlak olarak uygulamakta olup, gayrımenkule dair bir ilâmın icrasının o gayrımenkulün bulunduğu mahalden başka bir yerdeki icra dairesinden de istenebileceği görüşündedir (227). Bu durum karş1sında İcra Hukuku (ilâmlı veya ilâmsız) bakımından gayrımenkullerle ilgili yetkinin prensip itibariyle kamu düzeninden addedilmediği söylenebilir. Fakat bazı hallerde bu yetki İcra Hukukunda da kamu düzeninden sayılmaktadır. Meselâ mahcuz gayrımenkul ancak bulunduğu yerin icra dairesince paraya çevrilebilir (IÍK m. 50). Halbuki gayrımenkul rehninin paraya çevrilmesi söz konusu olduğu zamanlar, kamu düzeni esası carî olmamakta ve gayrımenkulün icra dairesinden başka icra dairelerinin yetkileri de kabul edilmektedir (IIK m. 148) (228) (229).

\section{2) Karşılık dâvanın 13 üncü maddenin yetkisine giren bir meseleye ilişkin olması}

Kanunumuz bu hususa özel olarak temas etmemiștir (229a). Karşıllı dâvada yetkiyi genel olarak tayin eden HUMK m. 14 hükmüne göre, esas dâvanın açılmış olduğu mahkeme, karşıllık dâvaya da bakmaya yetkili olacaktır. Fakat bunun için, daha doğrusu bir dâvanın karşılık dâva addedilebilmesi için belli bazı şartların gerçekleşmesi icap eder. Bu şartlar takas ve mahsup talebi (HUMK m. 204/1) ve asıl dâva ile karşıllık dâva arasında irtibat bulunmasıdır (HUMK m. 205).

Eğer karşılık dâva kesin yetkiye meselâ 13 üncü maddenin kapsamına giren bir hususa 'ilişkin olursa durum ne olacaktır?

(226) İ́D 14.11.1947, 3997/..... ve 23.3.1946, 977/1332 (Karaok, m. 443 s. 757$)$.

(227) Kuru, İH s. $360-361$.

(228) Kuru, İH s. $89-90$.

(229) İcra-Iffâs Kanunumuz gayrımenkullerin tahliye ve teslimi, irtifak haklarına dair ilâmların icrası ve ipoteğin paraya çevrilmesi gibi icra yollarını 26-29, 31 ve 143 vd. maddelerinde düzenlenmiştir.

(229a) Isviçre'de ise bazı kantonlar bu konuyu usûl kanunlarında düzenlemişlerdir (bk. von der. Crone, age. s. 60/75). 
Bir fikre göre (230) bu takdirde 14 üncü madde hükmünün uygulanmaması ve karşılık dâvanın esas dâvaya bakan mahkemede açılamaması icap eder (231). Fakat şayet esas dâvanın açıldığı yer karşıllk dâva için de tespit edilen kesin yetkili yer mahkemesi ise mesele yoktur. Bu fikir kesin yetkiye tâbi ikinci dâvanin m. 14'e uygun olarak birinci dâvanın açılmış olduğu yer mahkemesinde açılması gerektiğini kabul etmemesi bakımından gayet isabetlidir. Ancak bu takdirde ikinci dâvanın bir karşılık dâva özelliğini haiz olup olmayacağı konusunda tereddüt doğacaktır. Zira karşllık dâvanın yukarda bahsedilen takas ve mahsup veya irtibat gibi esasa ait kanunî şartlarından başka, doktrince kabul ve tespit edilen usule ilişkin hazı şartları daha vardır (232). Bunlardan bir tanesi de karşılık dåvanın esas dâvanın açılmış olduğu mahkemede ikame edilmiş olmasıdır (233). Hal böyle olunca açılmış olan bir gayrımenkul ayın dâvasına bağlı bulunan yine gayrımenkul ile ilgili aynî karakterde ikinci bir dâvaya, kamu düzeni dü şüncesiyle o gayrımenkulün bulunduğu yer mahkemesinde mi, yoksa birinci dâvaya tabî olarak bunun açılıp görülmekte olduğu mahal mahkemesinde mi bakılması gerekeceği meselesi ortaya çıkacaktır. Kamu düzeni düşüncesi herhalde ağır basacağından ikinci dâvanın, müddeabihi olan gayrımenkulün bulunduğu yer mahkemesinde açılması doğru olacaktir (233a). Birinci açılan dâva ile ikinci açılan dâvanın müddeabihleri olan gayrımenkullerin aynı mahkemenin yetkisine tabî bulunmaları (aynı kaza çevresi içinde olmaları dolayısıyla) halinde zorluk çıkmayacak, her iki dâvaya da bakmaya esasen aynı mahkeme yetkili bulunduğundan, dâvaların aynı mahkemece yürütülmesi mümkün olacaktır. Ancak bi. rinci ve ikinci dâvaların müddeabihlerini teşkil eden gayrımenkuller başka başka mahkemelerin yetkisine tabî (ayrı kaza çevre.leri içinde bulunmaları dolayısıyla) iseler, o zaman ikinci açılan «dâvalar arasında bağlılık» şartını haiz gayrımenkul ayın dâva-

(230) Belgesay, age. m. 14 No. 2; Kuru, HMU s. 124.

(231) Karş. ZPO $\$ 33 /$ II

(232) Bk. Karafakih, age. $152-153$, Bilge MYH s. $410-411$.

(233) Bilge, MYH s. 410.

(233a) Birçok tsviçre kantonunda bu durum kanun tarafından da tespit edilmiş bulunmaktadır (bk. von der Crone, age. s. 6i) ve 60/75). 
S1 (234) kamu düzeni düşüncesiyle kendi mahkemesinin yetkisine tabî bulunacak, fakat bu durumda karşllık dâvaların usulî şartlarından olan her iki dâvanın da aynı mahkemece yürütülmesi prensibi gerçekleşmemiş olacağından, ikinci dâvayı bir karş̧lık dâva olarak nitelendirmeye imkân bulunmayacak, dolayısıyla bir karşlık dâva ilişkisi doğmayarak dâvalar başka başka yer mahkemelerinde birbirlerinden müstakil birer aslî dâva olarak yürütüle. ceklerdir (234a).

2) 13 üncü maddeye ilişkin uyuşmazlıklar dolayısıyla alınacak ihtivatî tedbirler için yetkili mahkeme

$\mathrm{Bu}$ gibi uyuşmazlıklar dolayısıyla alınacak ihtiyatî tedbirler, gayrımenkul malların haczi ve yed'i adle tevdii (HUMK m. 101/1) veya ihtilâflı gayrımenkulün muhafazası için lâzım gelen her türlü tedbirin alınması (HUMK m. 101/2) şeklinde olurlar. İhtiyatî tedbirde yetkili mahkemeyi HUMK m. 104 (235) belirtmektedir. $\mathrm{Bu}$ maddeye göre ihtiyatî tedbir ya dâva açlmasından önce veya sonra alınabilir. Dâva açılmasından sonra bütün ihtiyatî tedbirlerin dâvaya bakmakta olan mahkemeden isteneceğine dair olan ikinci fıkra hükmü emredici karakterdedir ve 13 üncü maddeyi ilgilendiren uyuşmazlıklar dolayısıyla dâva açlmasından sonra alınacak ihtiyatî tedbirler bakımından da bu konuda bir istisna söz konusu olamaz. Maddenin birinci fıkrası hükmü ise, dâva açılmadan önce alınacak olan ihtiyatî tedbirlerdeki yetki meselesini hükme bağlamaktadır. Bu hükme göre dâvadan önce ihtiyatî tedbir yine esas dâvaya bakmaya yetkili olan yer mahkemesinde (mes. gayrımenkulün bulunduğu yer mahkemesi) yahut da tedbirin en az masrafla ve en süratli şekilde yerine getirilebileceği yer mahkemesinde alınabilecektir. Acaba bu son imkân gayrımenkul ayın dâvaları için alınacak olan ihtiyatî tedbirler bakımından d? düşünülebilir mi? Ekseri hallerde gayrımenkulün bulunduğ̆u yer dâvadan evvel o gayrımenkulün aynına ilişkin uyuşmazlık bakı-

(234) Meselâ haricen satılan gayrımenkullerde açılan fuzulì müdahalenin men'i dâvasına karşılik ödenen semenin iadesine ve zarurî ve faydalı masrafların tazminine kadar o gayrımenkulü elde tutma (hapis) hakkının ileri sürülmesi; bina sahibinin arsayı temıllük edebilmesine dair MK m. 650 hükmünü de burada zikredebiliriz.

(234a) Karş. von der Crone, age. s. 60-61.

(235) Karş. ZPO § 942. 
mindan ihtiyatî tedbiri de en çabuk ve en az masrafla sağlayabilecek olan yerdir. Fakat eğer bu imkânı temin edebilecek olan mahkeme gayrımenkulün bulunduğu yer mahkemesi değilse durum ne olacaktır? Fikrimizce burada dâva karakterini haiz olmayan bir mahkeme işlemi bahis konusu olduğundan, yani mahkemenin buradaki faaliyeti kazaî değil idarî bir tasarruf karakterinde bulunduğundan, burada mutlaka gayrımenkul mahkemesinin yetkisini gerektiren kamu düzeni gibi unsurlar söz konusu olmayacaktır. 13 üncü maddenin kesin yetkisi sadece görülmekte olan dâva ve bunun neticeleri bakımındandır. Bu itibarla dâvadan evvel 104 üncü maddenin birinci fıkrasına uygun olarak ihtiyatî tedbirin gayrımenkul mahkemesinden başka bir mahkemece alınmış olmasının hiçbir mahzuru bulunmaması icabeder (236).

\section{4) Gayrınıenkul dâvalarında görev}

Gayrımenkul dâvalarında görev meselesi Usûl Kanunumuzda yetkide oldı̣̆̆u gibi özel bir hükümle (m. 13) düzenlenmiş deǵildir. Bu gibi dâvalar bakımından göreve ilişikin kaideler dolâylı olarak birkaç Inadde içine serpiştirilmiş bulunmaktadır.

Gayrımenkul ayın dâvaları hakkında hangi mahkemenin görevli olacağı HUMK m. 8/1 den anlaşılmaktadır. Bu hükme göre değer ve miktarı bin lirayı (237) geçmeyen gayrımenkul dâvalarını görmeye sulh mahkemeleri görevlidir. Şu halde bu miktarı aşan iddialar için görevli mahkeme asliye mahkemesi olacaktır (238). Ancak değeri 1000 TL. nın altında olan bir gayrımenkul ayın dâvası yanlışlıkla gayrımenkulün bulınduğu yerdeki asliye mahkemesinde açılıp orada karara bağlandıktan sonra, artık bu hüküm aleyhine üst derece mahkemesinde görevsizlik itirazında bulunulamıyacağı hususundaki esas (HUMK m. 7/III) gayrımenkul dâvaları bakımından carî olamıyacak ve keşif sırasında

(236) Tapulama Kanunu, tapulama mahkemelerinin, (m. 6, 49/I), vazifelerine giren işlerde (m. 47/I) ihtiyatî tedbir. kararı verebileceklerini hükme bağlamıștır (m. 47/II C. 1).

(237) Müddeabih paradan başka birşey olup da taraflar kıymet üzerinde anlaşamazlarsa kıymeti mahkeme tayin edecektir (HUMK $\mathrm{m}$. $2 /$ II).

(238) Ad. Bak. Huk. İs. Md. tamim ve mütalâası, 6.6.1953 No. 6911 (Karaok, m. 13 s. 135). 
gayrımenkulün değeri 1000 TL. ndan az takdir edilmişse dâvanın asliye mahkemesinde görülüp neticelendirilmesi imkânsız olacak$\operatorname{tir}(239)$.

İtifak haklarına ilişkin dâvalar, üzerine irtifak hakkı taallûk eden malın bulunduğu mahallin asliye veya sulh hukuk mahkemesinde görülür (bk. HUMK m. 13/II C. 2). Burada görevin tayini biraz değişik olup, irtifak hakkının hakim gayrımenkule getirdiği değer fazlasıyla, hâdim gayrimenkule yüklediği değer noksanından hangisi daha fazla ise görevli mahkeme buna göre tâyin olunacaktır (HUMK m. 6) (240).

Eğer dâva birden çok gayrımenkule ilişkin ise, dâva bunların değerleri toplamına göre (HUMK m. 3 C. 1) gayrimenkullerden birinin bulunduğu yer (HUMK m. 13/III) sulh veya asliye hukuk mahkemesinde açlacaktır.

Şayet gayrımenkule ilişkin asıl dâva ve karşılık dâva aynı mahkemenin yetkisine tabî iseler, görevin tayini 5 inci maddeye göre, bu dâvalardan değeri yüksek olana göre tayin olunacaktır. Fakat eğer gayrımenkullerin ayınlarına ilişkin birinci dâva ile onunla arasında bağlllık ilişkisi bulunan ikinci dâva başka başka mahkemelerin yetkisine tabî bulunmaktaysalar (241), bu takdirde dâvalara bakacak olan mahkemelerin görev bakımından da ayrılmalarında (sulh veya asliye) hiçbir sakınca bulunmayacaktir.

Gayrımenkul ayın dâvaları bakımından olduğu kadar, gayrımenkullere ilişkin şahsî haklar cihetinden de görevli mahkeme müddeabihin değerine göre belirtilecektir. Bunun tek istisnası gayrımenkullerin tahliyesi dâvaları hakkındadır. Gayrımenkullere ilişkin şahsî hak dâvalarından olan bu gibi dâvaları görmekle yalnız sulh hukuk mahkemeleri (242) görevlidirler (HUMK m. 8/4. $6570 \mathrm{SK} \mathrm{m}$. 10/I) (243).

İstimlâk dâvaları müddeabihin değerine bakılmaksızın asliye mahkemelerinde görülür (6830 SK m. 14, 19).

(239) Ad. Bak. Huk. İş. Md. nün dip not 168 a'da zikredilen tamimi.

(240) Karş. ZPO \& 7.

(241) Bk. dip not 231 civarı.

(242) Karş. Mieterschutzgesetz $\$ 7$.

(243) Bu kaidenin istisnası için bk. $6570 \mathrm{SK} \mathrm{m}$. 10/II. 
Kat Mülkiyeti Kanunu, bu kanunun konusunu teşkil eden meseleler hakkında çıkacak uyuşmazlıklar için genellikle sulh mahkemesini görevli kılmıştır (m. 33/I, 52/III, 54/II, III). Bazı hallerde ise, sadece hâkimden söz edilmiş, görev ciheti belirtilmemiştir (634 SK m. 25/I, 26/III, 47/II). Bunlardan m. 25/I deki halde görevli mahkemenin sulh hukuk mahkemesi olmasi gerektiği yine aynı maddenin üçüncü flkrasinın (b) bendinin ifadesinden anlaşlmaktadır. Aynı şekilde $\mathrm{m}$. 26/III ve $47 / \mathrm{II}$ deki durumlardà da görevli mahkeme sulh mahkemesi olacaktır (244). Yine 26 nc1 maddenin üçüncü fikrasında bahis konusu edilen zararın tazmin edilmesi gerekirse, görevli mahkeme zararın miktarına göre (bin liradan az veya çok) sulh hukuk veya asliye hukuk mahkemesi (HUMK m. 8/I) olmalıdır (245).

Tapulama Kanununa göre, «genel mahkemelere ait olup da, bu kanunun tatbikiyle ilgili dâva ve işleri..... görmek üzere her bölgede tek hâkimli ve Asliye Mahkemesi sıfatını haiz yeter say1da Tapulama Mahkemesi kurulur» (m. 6/I). Şu halde tapulama mahkemesi adetâ bir asliye mahkemesi vasıf ve karakterini haiz. olacaktır. Esasen görev bakımından bu iki mahkeme arasında fazla bir fark gözetmemenin sonucu olarak aynı dâvanın muayyen müddetler zarfinda hem tapulama mahkemesi, hem de mahallî mahkemece görülmesinde bir sakınca gözetilmemiștir (246).

2613 sayll Kadastro ve Tapu Tahriri Kanunu ile tayin edilmiş bulunan kadastro işlerini görmeye görevli bulunan kadastro mahkemeleri (m. 12), 5572 sayll kanunun 2 nci maddesi ile kaldırılmış olup, bugün kadastro işlerinde çıkacak olan uyuşmazlıkları görmeye adalet mahkemeleri (asliye mahkemesi) görevli bu* lunmaktadurlar.

Münhasıran NK işleri için çılkarılmış bir NK - Kanunumuz. olmadığı için, NK hakkındaki görev hülkümlerini de toplu olarak (247) bulmamız imkânsızdır. Kanunlarınız NK işleri için ba-

(244) Karş. Çatalkaya-Tarıkoğulları, Kat Mülkiyeti Kanunu Şerhi, Ankara 1965, m. 26 s. 92 , m. 47 s. 124.

(245) Karş. Çatalkaya-Tarıkoğulları, KMKŞ. m. 26 s. 92.

(246) Bk. Tapulama Kanunu m. 50, 51 ve dip not $217-219$ civari.

(247) Almanya'da NK işlerinde görevli mahkeme hemen daima sulh mahkemesidir; Avusturya'da ve İsviçre Kantonlarında da görevli mahkeme kaideten sulh mahkemesidir (Kuru, NK s. 129). 
zen açıkça sulh, bazen asliye mahkemelerinı görevli kılmışlar, bazen de sadece hakim veya mahkemeden bahsetmekle yetinmişler$\operatorname{dir}(248)$.

Durum gayrımenkullere ilişkin NK işleri yönünden de değişik değildir. Gayrımenkulün aynına ilişkin olan MK m. 639 ve 935/I deki NK işlerinde sadece «mahkeme»den, MK $\mathrm{m} .826 / \mathrm{I}$ ve $934 / \mathrm{III}$ deki işlerde ise yanlız «hâkim»den bahsedilmiş, MK m. 735 de söz konusu edilen NK işinde ise bu kavramlardan hiçbirisi kullanılmamıştır. Gayrımenkulün aynına ilişkin olmayan NK işlerinden MK m. 795 de açıkça sulh hâkiminden bahsedilmiş, MK m. 839, 840 daki hallerde ise yine sadece hâkimden söz edilmiştir. Görevli hakim veya mahkemenin belirtilmediği hallerde, bunu asliye hakimi veya mahkemesi olarak anlamak gerekir (249). Zira Türk Hukukunda asliye mahkemelerinin görevleri asıl, sulh mahkemelerininki ise istisnai (HUMK m. 8) mahiyette olduğundan ve mahkemelerin görevleri kanunla belli edileceğinden, NK işlerinde de kanunun görev bakımından sadece hakim veya mahkemeden söz ettiği hallerde bunu asliye hakimi veya mahkemesi olarak anlamak yerinde olacaktır (250). Şu halde MK m. 639, 826/I, 934/III deki gayrımenkulün ayına ilişkin NK işleriyle, ayına ilişkin olmayan m. 839 ve 840 daki NK işlerinde görevli mahkeme bu prensibe uy. gun olarak asliye hukuk mahkemesi olacaktır. MK m. 795 deki aymla ilgili olmayan NK işinde ise sulh mahkemesinin görevli olduğu açıç̧a söylenilmiş bulunmaktadır. Buna karşılık ayına ilişkin $\mathrm{MK}$ m. 935/I ile m. 735'in NK işlerinde tereddüt ortaya çkabilir. Gerçi MK m. 935/I deki halde «mahkeme» den söz edilmiş ise de, bunun genel kaideye uygun olarak asliye mahkemesi olarak anlaşlmasına Tapu Sicili Nizamnamesi'nin 107 nci maddesi hükmü karșisında imkân yoktur ve bu madde gereğince $\mathrm{MK} \mathrm{m}$. 935/I deki NK işi için görevli mahkemenin suih hukuk mahkemesi olmasi gerekir. MK m. 735 de bahsedilen NK işinde ise «mahkeme» veya «hakim» gibi bir terim dahi kullanılmamıştır. Ancak bu maddede söz konusu edilen defter tutma işi HUMK m. 553-560 anlammda bir tahrir ameliyesi olduğun-

(248) Kars. Kuru, NK s. 130 ve dip not 23-26.

(249) NK'da görevin tayini bakımından HUMK'un koymus olduğu 1000 TL. kıstası (m. 8/1) tabiatıyla söz konusu olmiyacaktır. Cünkü bu ölçü Nizalı Kaza alanındaki dâvalar için konulmuştur.

(250) Bk. Kuru, NK s. $130-131$. 
dan, Burada Usûl Kanununun bu maddeleri uygulanacaktrı: HUMK m. 554'e göre ise, tahrir işlerinde görevli hakim (mahkeme) sulh hukuk hakimi (mahkemesi) olacaktır.

Kat Mülkiyeti Kanunu ile de tespit edilmiş olan bazı NK işleri bulunmaktadır. Meselâ yönetici atanması (m. 34) ve yönetim plânının değiştirilmesi (m. 28/III) gibi. Bu işlemler için adı geçen maddelerde sulh mahkemesinin görevli olacağı açıkça belirtilmiṣ bulunmaktadır.

\section{5) Gayrımenkul dâvalarında tahkim}

Bu bölümde gayrımenkul dâvaları için tahkim yoluna başvurmanın mümkün olup olmıyacağı ve eğer mümkünse yetki meselesinin nasil düzenlenmesi gerekeceğine değinilecektir. Ancak bunun için ihtiyarî ve mecburî tahkim bakımından durumu ayrı ayrı incelemek icabeder.

a) Ga yrımenkul d âva 1 a r ln d a ihtiyarî́ t a hk i m

13 üncü maddenin kapsamma giren dâvalar bakımından gayrımenkul mahkemesinin kesin yetkisi alâkadar kişilerin aralarında anlaşmalariyla tamamen bertaraf edilemez (251). Fakat taraflarm aralarındaki uyuşmazlığın hakemlerce çözümlenmesi hususunda bir anlaşma yapmalarına herhangi bir engel bulunmamak gerekir (252). Yargitayın aksi yönde olan bir kararında (252 a) isabet yoktur. Zira ilgililerin uyuşmazlığın hakemler yoluyla çözümlenmesini kabul etmeleri demek, onların dâvaları için . yetkisiz olan bir mahkemeyi yetkili kılmak istemeleri anlamma gelmez. 13 üncü madde sadece uyuşmazlı̆̆ın gayrımenkulün bulunduğu yer mahkemesinden başka bir mahal mahkemesinde (fiilen, coğrafî bakımdan başka bir yargı çevresinde) çözümlenmesini kamu düzeni düşüncesiyle yasaklamıştır. Bu yasak hükmünü dâvaya bakacak yargı yerinin tâbi bulunacağı yargılama şartları bakımından

(251) Bu prensip ZPO $\$ \S 38$ ve 40/II de kanunî ifadesini bulmuştur.

(252) Aynı fikirde : Stein-Jonas, age. \$ 24 IV; Ansay, age. s. 408; ayrıca bk. Postacıŏlu, age. s. 557; Bilge, MYH s. 647; Kuru, HMU s. 518.

(252a) «İçtihadı birleştirmeden sonra dahi taşınmaz mal uyuşmazlıklarının hakem tarafından çözülmesi şartı batıldır. (Çünkü intizamı âmme ile ilgilidir» (4. HD. 13.9.1965, 965/6722 «Ersoy, s. 493»). 
kamu düzeni ile ilgisi olmayan diğer hususları da kapsıyacak şekiide genişletmeye imkân yoktur. Kaldı ki HUMK nun tâhkimle ilgiii hükümlerinde (m. 516-536) gayrımenkuller hakkındaki dâvaların hakemlerce görülmesini açık olarak yasaklayan bir ifade de bulunmamak tadır (253). Halbuki kanun koyucu hakemlerce görülmesini istemediği, münhasıran iki tarafın arzusuna tâbi olmayan evlenme, boşanma, nesep vb. meseleler hakkında böyle önleyici bir hüküm (HMUK m. 518) koymak lüzum ve zaruretini hissetmiştir.

Ancak bir gayrımenkul ayın uyuşmazlığ 1 hakkında tahkim yoluna gidilirken 13 üncü maddeye hakim olan esastan, onun konulmasındaki gayeden uzaklaşmamaya da dikkat etmek gerekir. 13 üncü maddenin kamu düzeninden addedilmesine sebep olan bu düşünceler (254), hakem mahkemeleri bakımından da öncelikle dikkat nazarına alınmak icabeder. O halde uyuşmazlı̆̆ın hakemler tarafından çözümlenmesi hususunda yapılan anlașmaya (HUMK m. 516, 517), hakem heyetinin dâvanın başından sonuna kadar gayrımenkulün bulunduğu yerde kazai faaliyette bulunması gerektiği şelklinde bir şart ilâve etmek yerinde olur. Böyle bir kayıt adetâ kesin yetkiye iliş̧kin bir yargilama şartı olacağından, bunun bulunmayıșı, hakem mahkemesinin o uyuşmazlık bakımından yetkili olmaması neticesini doğurabilecektir. Zira bilindiğgi gibi mahkemenin yetkili bulunması kesin yetki hallerinde bir dâva şarı olarak kabul edilmektedir (255). Şu halde tahkim anlaşmasında böyle bị şartın bulunmaması, hakem mahkemesinde,dâva şartlarından birinin elssik olması sebebiyle dâvanın dinlenmemesi, dolay!sıyla reddedilmesini gerektirebilir (255 a).

13 üncü maddenin kapsamına girmeyen gayrımenkul dávaları hakkında ise, buradaki yetkinin kamu düzeninden addedilmemesi sebebiyle. uyuşmazlığın hakemlerce çözümlenmesi herhang: bir kayıt ve şartla bağlı olmayarak kararlaştırılabilecektir.

(253) 2613 sayll Kadastro ve Tapu Tahriri Kanunu ile tahkime müsaade edilmiştir (bk. m. 30, 32, 33). «Tapuda tescil edilmemiş olan gayrimenkullerin taksimi yolunda tahkim yoluna gidilemez» ( 5 . HD 17.7.1948 «Ansay, age. s. 408/894»).

(254) Bk. dip not 42 civar1.

(255) Bilge, MYH s. 3571 d; Schönke, age. § 45 III 1 e.

(255a) Postacıoğlu, gayrımenkullere ait tahkim anlaşmalarının, resmî şekilde vapılmadıkça, muteber olmayacağı görüşündedir (age. s. 557, 558): Bilge, bu görüşün tartışılabileceği fikrindedir (MYH s. 647). 
b) Gayrımenkul dâvaları 1 a me c bur t a h $\mathrm{ki} \mathrm{m}$

Bu konuda 3533 sayılı kanun (256) hükümleri uygulanır. Bu kanun umumî, mülhak ve hususî bütçelerle idare olunan daireler ve belediyelerle, sermayesinin tamamı devlete, belediye veya hususî idarelere ait daire ve müesseseler arasındaki uyuşmazlıkların tahkim yoluyla hallini düzenlemektedir. Kanuna göre, adı geçen teşekküller arasında çıkan uyuşmazlıklardan adalet mahkemelerinin görevleri dahilinde bulunanlar bu kanunda yazılı olan tahkim usulüne göre çözümlenecektir (m. 1). Eğer bu teşekküller ve kurumlar arasında çıkan uyuşmazlıklar gayrımenkullere ilişkin ise, o gayrımenkulün bulunduğu mahallin ve taraflar ayrı ayrı yer. lerde bulunuyorlarsa dâvalı durumunda olan daire veya kurumun ve dâvalılar birden fazla olurlarsa, bunlardan birisinin bulunduğu yerin yüksek dereceli hukuk mahkemesi reisi veya hakimi tarafindan hakem sifatıyla hallolunacaklardır (m. 4). Bu hakemler tarafından verilecek kararlara karşı yeniden incelemeyi gerektirecek haklı sebepler bulunmaktaysa, kararın tebliği tarihinden itibaren otuz gün içinde kararı veren hakeme itirazda bulunulabilir. İtiraz üzerine verilecek kararlar kesindir (m. 6/II, III). 